University of Warwick institutional repository: http://go.warwick.ac.uk/wrap This paper is made available online in accordance with publisher policies. Please scroll down to view the document itself. Please refer to the repository record for this item and our policy information available from the repository home page for further information.

To see the final version of this paper please visit the publisher's website. Access to the published version may require a subscription.

Author(s): D.L. Carroll, T.F. Kemp, T.J. Bastow and M.E. Smith Article Title: Solid-state NMR characterisation of the thermal transformation of a Hungarian white illite Year of publication: 2005 Link to published version: http://dx.doi.org/10.1016/j.ssnmr.2005.04.001 Publisher statement: None 


\title{
Solid State NMR Characterisation of the Thermal Transformation of a Hungarian White Illite
}

\author{
D. L. Carroll ${ }^{\mathrm{a}}$, T. F. Kemp ${ }^{\mathrm{a}}$, T. J. Bastow ${ }^{\mathrm{a}, \mathrm{b}}$ and M. E. Smith ${ }^{\mathrm{a}} *$
}

(a) Department of Physics, University of Warwick, Coventry, CV4 7AL, UK.

(b) CSIRO, Division of Manufacturing and Infrastructure Technology, Private Bag 33, South Clayton MDC, Clayton, Victoria 3169, Australia.

\begin{abstract}
${ }^{1} \mathrm{H},{ }^{27} \mathrm{Al},{ }^{29} \mathrm{Si}$ and ${ }^{39} \mathrm{~K}$ solid state NMR are reported from a Hungarian illite 2:1 clay for samples heated up $1600^{\circ} \mathrm{C}$. This single phase sample has a small amount of aluminium substitution in the silica layer and very low iron-content ( $0.4 \mathrm{wt} \%)$. Thermal analysis shows several events that can be related to features in the NMR spectra, and hence changes in the atomic scale structure. As dehydroxylation occurs there is increasing $\mathrm{AlO}_{4}$ and $\mathrm{AlO}_{5}$-contents. The silica and gibbsite layers become increasingly separated as the dehydroxylation progresses. Between 900 and $1000^{\circ} \mathrm{C}$ the silica layer forms a potassium aluminosilicate glass. The gibbsite-layer forms spinel $/ \gamma-\mathrm{Al}_{2} \mathrm{O}_{3}$ and some aluminium-rich mullite. Then on heating to $1600^{\circ} \mathrm{C}$ changes in the ${ }^{29} \mathrm{Si}$ and ${ }^{27} \mathrm{Al}$ MAS NMR spectra are consistent with the aluminosilicate glass increasing its aluminium-content, the amount of mullite increasing probably with its silicon-content also increasing, and some $\alpha-\mathrm{Al}_{2} \mathrm{O}_{3}$ forming.
\end{abstract}

Key words:illite, solid state NMR, clay mineral, thermal processing, dehydroxylation

* Address for correspondence: M.E. Smith, Department of Physics, University of Warwick, Coventry, CV4 7AL, UK. Email: M.E.Smith.1@warwick.ac.uk 


\section{Introduction}

Clays form a technologically important group of minerals that have numerous industrial uses being major components of whiteware products and fireclay bodies such as bricks, roof tiles and cements. Clay firing is a very mature part of the ceramics industry and this thermal reaction is amongst the most studied of all ceramic reactions [1-3]. There is usually a clear idea about the equilibrium end point of the thermal breakdown, but the details of the intermediate states which usually have significant amorphous components have remained largely elusive. To obtain a fundamental understanding of the thermal breakdown mechanism that will allow optimisation of the processing of clay minerals it is necessary to study these materials with leading-edge, modern spectroscopic techniques that can provide new unambiguous structural information.

Clay minerals are layer structures with the layers lying in the ab plane which are then stacked up parallel to the c-axis. The layers are of 2 types; silica-like layers made up of $\mathrm{SiO}_{4}$ units and gibbsite-like layers made up of $\mathrm{AlO}_{4}(\mathrm{OH})_{2}$. The two main groups of clays are those which comprise repeat units of one silica and one gibbsite layer; 1:1 clay minerals, and those made up of a sandwich of a single gibbsite layer between two silica layers; 2:1 clay minerals. Between these repeated layers there are interlayer spaces (Figure 1). Complexity in clays may arise through atomic substitutions that can occur within these layers. Some examples are aluminium substituting for silicon in the silica-like layers, and iron and magnesium substituting for aluminium in the gibbsite-like layer. These substitutions usually produce a negative layer charge which then needs to be balanced by cations (e.g. $\mathrm{Na}^{+}, \mathrm{K}^{+}$,) which reside in the interlayer space. The interlayer space can also accommodate varying amounts of water to hydrate these cations. The various layer substitutions and interlayer contents can produce significant changes in the properties of the clay including its thermal breakdown mechanism.

An important group of 2:1 clay minerals termed illite was first proposed in 1937 [4] to denote mixtures of minerals, including muscovite and feldspar whose physical properties resemble 
those of the mica family. It has been generally accepted that the main difference between mica and illite is that micas contain more potassium as interlayer cations, whereas illite contains more water and silica. The general formula for illite can be expressed as $\mathrm{K}_{1.5} \mathrm{Al}_{4}\left(\mathrm{Si}_{6.5} \mathrm{Al}_{1.5}\right) \mathrm{O}_{20}(\mathrm{OH})_{4}$ [5]. Earlier studies on illite-rich clays [6-9] using various techniques such as ESR and Mössbauer show there are four main reaction processes which occur; viz. dehydration, dehydroxylation, structural breakdown and re-crystallisation. Interlayer water is driven off by $350-400^{\circ} \mathrm{C}$, followed by dehydroxylation between $450-700^{\circ} \mathrm{C}$, and irreversible structural breakdown $\sim 900^{\circ} \mathrm{C}$. The formation of spinel typically occurs at $1000^{\circ} \mathrm{C}$ and continues to increase in amount and particle size with increasing temperature. Other phases can form such as haematite, corundum, mullite and glassy phases at higher temperatures, depending on the composition [9].

The presence of aluminium and silicon makes clays an obvious target for solid state NMR because both of these nuclei are very amenable to such study [10-13]. There have been various multinuclear NMR reports (especially ${ }^{29} \mathrm{Si}$ and ${ }^{27} \mathrm{Al}$ ) of the thermal decomposition of clay minerals. The most comprehensive NMR data set from clays has been for 1:1 clay minerals, such as kaolinite [14-24] and related phases such as halloysite [25]. For 2:1 type clay minerals pyrophyllite is a cation-free clay that has no iron and it shows different thermal breakdown characteristics from the cation-free 1:1 clay minerals, with much more $\mathrm{AlO}_{5}$ in the intermediate dehydroxylate state [26-28]. Studies on muscovite using solid-state ${ }^{29} \mathrm{Si}$ and ${ }^{27} \mathrm{Al} \mathrm{NMR} \mathrm{[29]}$ showed that the dehydroxylate phase decomposes $\left(\sim 1100^{\circ} \mathrm{C}\right)$ by separation of the silica layers, which then combine with the cations $\left(\mathrm{K}^{+}\right)$forming a feldspar-like phase. The remainder of the structure forms a spinel $/ \gamma-\mathrm{Al}_{2} \mathrm{O}_{3}$ which then transforms into aluminous mullite, and then corundum, and on further heating the mullite becomes more silica-rich by reacting with the feldspar-like phase.

There have been more recent attempts to carry out multinuclear solid state NMR on clays that are more complex, often smectite-illite mixtures, that more closely resemble clays that are 
used industrially. A calcium montmorillonite (Fuller's Earth) showed subtle structural changes of the layers up to $\sim 900^{\circ} \mathrm{C}$ when there is a significant break down into alumina-rich and silica-rich domains [30]. In Lode an illite-rich clay of the mica group with a small amount of interstratified smectite, it was observed that compared to other 2:1 clays ${ }^{27} \mathrm{Al}$ MAS NMR showed very little $\mathrm{AlO}_{5}$ in the dehydroxylate, and at high temperatures an aluminosilicate glass was the dominant phase [31]. The study of Lode indicated that exactly the same spectra were obtained from powdered, pressed and extruded samples [31]. Another model illitic clay, Silver Hill, again showed no $\mathrm{AlO}_{5}$ in the intermediate dehydroxylate [32].

One of the key difficulties with these previous NMR studies of illites is that they typically had iron-contents of 4.8-7.1 wt $\% \mathrm{Fe}_{2} \mathrm{O}_{3}$ which affects the NMR signal intensity, losing signal from those nuclei close to the paramagnetic centres. This means that the spectra can only really be interpreted qualitatively. For example, in Lode for silicon $\sim 41 \%$ of the expected intensity was observed at all temperatures, whereas for aluminium the signal intensity decreased from $41 \%$ in the room temperature sample to only $22 \%$ in the sample heated to $1200^{\circ} \mathrm{C}$. As new phases form, the iron partitioning is often not uniform. In Lode and Silver Hill samples X-ray diffraction (XRD) showed that mullite forms, but it was absent in the NMR data. Elemental analysis shows that the iron-content of the mullite is significant and is subsequently lost from the NMR spectra.

This study reports multinuclear $\left({ }^{1} \mathrm{H},{ }^{27} \mathrm{Al},{ }^{29} \mathrm{Si},{ }^{39} \mathrm{~K}\right)$ magnetic resonance from a Hungarian white illite which has a very low iron-content $(0.4 \mathrm{wt} \%)$. This greatly extends previous NMR studies of illitic clays since the intensity complications that arise from paramagnetic ions are not present and quantitatively accurate results should be obtained. This study includes quantitative ${ }^{1} \mathrm{H}$ measurements, ${ }^{27} \mathrm{Al}$ at two applied magnetic fields (14.1 and $18.8 \mathrm{~T}$ ) and ${ }^{39} \mathrm{~K} .{ }^{39} \mathrm{~K}$ has a natural abundance of $93.1 \%$ and a relative receptivity of its central transition comparable to that of ${ }^{13} \mathrm{C}$. It has been relatively little studied because it has a small magnetic moment making it a low- $\gamma$ quadrupolar nucleus [11,33]. However in the few ${ }^{39} \mathrm{~K}$ NMR studies of solids that have been 
carried out spectra are usually readily obtained. For example static ${ }^{39} \mathrm{~K}$ NMR spectra from a range of model inorganic potassium salts showed relatively small dipolar coupling, resulting in sharp powder pattern features of the observed central transition allowing accurate extraction of the quadrupole parameters as chemical shift anisotropy appeared to make only a very small contribution [34]. In potassium-containing aluminosilicates it has been shown that from the position of the centre-of-gravity (cg) of the static ${ }^{39} \mathrm{~K}$ resonances, the tectosilicate orthoclase ( 205 ppm) could be distinguished from phyllosilicates in which the cg position is below $40 \mathrm{ppm}$ [35]. Potassium NMR could also distinguish structural and exchangeable potassium in the clay mineral montmorillonite as it undergoes wetting and drying [35]. For potassium aluminosilicate geopolymers the cg positions varied from $-47 \mathrm{ppm}$ (more typical of a hydrated potassium phase) in the unheated geopolymer, to $-120 \mathrm{ppm}$ in the material heated at $1300^{\circ} \mathrm{C}$, consistent with the position of an unheated feldspar [11].

\section{Experimental methods}

Chemical analysis of the white Hungarian illite studied here is shown in Table 1 which is typical for potassium illite (of model composition $\left(\mathrm{K}_{1.5} \mathrm{Al}_{4}\left(\mathrm{Si}_{6.5} \mathrm{Al}_{1.5}\right) \mathrm{O}_{20}(\mathrm{OH})_{4}\right)$ ). In the illite phase studied here there is some calcium and a very small amount of iron substitution for aluminium in the gibbsite layer. There were no other phases detected. Experiments were carried out on powders which were heated to and from the desired temperature in the range $200-1600^{\circ} \mathrm{C}$ by ramping at $2^{\circ} \mathrm{C} / \mathrm{min}$, and were held at temperature for 2 hours. Differential scanning calorimetry (DSC) was carried out on a Netzsch DSC 404 instrument using a ramp rate of $10^{\circ} \mathrm{C} / \mathrm{min}$ under a static air atmosphere up to $1300^{\circ} \mathrm{C}$. Thermogravimetric (TG) analysis was carried out on a Stanton Redcroft TG-750/770 instrument at a ramp rate of $10^{\circ} \mathrm{C} / \mathrm{min}$ under flowing air up to $1000^{\circ} \mathrm{C}$. XRD diffraction was carried out on powder samples using a Bruker D5005 powder diffractometer, with 
the patterns measured over a $2 \theta$ range $10-90^{\circ}$ at a scan rate of $0.15^{\circ}(2 \theta) / \mathrm{min}$ using $\mathrm{Cu}-\mathrm{K} \alpha$ radiation of wavelength $1.5418 \AA$.

${ }^{29}$ Si MAS NMR experiments were carried out on a Varian-Chemagnetics CMX 360 Infinity Plus (8.45 T magnetic field) spectrometer. ${ }^{29}$ Si magic angle spinning (MAS) NMR spectra were collected using a $6 \mathrm{~mm}$ probe spinning at $\sim 5 \mathrm{kHz}$. A 15 s recycle delay was employed with a $1.2 \mu$ s $\left(30^{\circ}\right)$ pulse, which allowed relaxed spectra to be obtained. The spectra were collected at 71.54 MHz and referenced against TMS at $0 \mathrm{ppm}$. The ${ }^{27} \mathrm{Al}$ MAS NMR spectra were collected at 18.8 $\mathrm{T}$ using a $4 \mathrm{~mm}$ probe spinning at $15 \mathrm{kHz}$ with $1 \mu \mathrm{s}\left(\sim 15^{\circ}\right)$ pulses and a $1 \mathrm{~s}$ recycle delay on a Varian Chemagnetics Infinity Plus spectrometer operating at a frequency of 208.39 MHz. The spectra were repeated at $14.1 \mathrm{~T}$ on a Varian-Chemagnetics Infinity spectrometer operating at a frequency of $156.37 \mathrm{MHz}$. The pulse and recycle delay conditions were the same as at $18.8 \mathrm{~T}$, but a $3.2 \mathrm{~mm}$ Chemagnetics probe was used spinning at $18 \mathrm{kHz}$. The ${ }^{27} \mathrm{Al}$ spectra were referenced against the $\mathrm{AlO}_{6}$ resonance of $\mathrm{Y}_{3} \mathrm{Al}_{5} \mathrm{O}_{12}$ at $0.7 \mathrm{ppm}^{\dagger}$. ${ }^{1} \mathrm{H}$ MAS NMR spectra were measured at 360.10 MHz using a Doty $4 \mathrm{~mm}$ probe spinning at $15 \mathrm{kHz}$. A recycle delay of $20 \mathrm{~s}$ was used to ensure that the samples were fully relaxed. For the proton spectra the samples were weighed and the integrated signal intensity was compared to that from an adamantane sample which was also weighed. A ${ }^{1} \mathrm{H}$ spectrum was run on the probehead with an empty rotor under identical conditions and the integral was subtracted from that of the samples. The adamantane was used as a secondary ${ }^{1} \mathrm{H}$ reference at $1.82 \mathrm{ppm} .{ }^{39} \mathrm{~K}$ static data was collected on a Varian Chemagnetics CMX 300 Infinity (7.05 T magnetic field) spectrometer at a frequency of $14.01 \mathrm{MHz}$ using a static $10 \mathrm{~mm}$ probe. An echo sequence was used with two $5 \mu$ s (sub- $90^{\circ}$ ) pulses separated by $200 \mu$ s with a recycle delay of $0.05 \mathrm{~s}$. Extended phase cycling was used to suppress direct magnetisation and any ringing [36]. ${ }^{39} \mathrm{~K}$ spectra were referenced against a static sample of solid $\mathrm{KBr}$ at $55.1 \mathrm{ppm}$.

\footnotetext{
$\dagger$ Note that the secondary shift references used here are quoted relative to the accepted zero shift references for each nucleus i.e. ${ }^{1} \mathrm{H}$ TMS, ${ }^{27} \mathrm{Al}$ in $\left[\mathrm{Al}\left(\mathrm{H}_{2} \mathrm{O}\right)_{6}\right]^{3+}$ in aqueous $1 \mathrm{M} \mathrm{Al}\left(\mathrm{NO}_{3}\right)_{3}$ and ${ }^{39} \mathrm{~K}$ as $\mathrm{K}^{+}$in aqueous $0.1 \mathrm{M} \mathrm{KCl}$.
} 


\section{Results}

DSC results show a good deal of structure (Fig. 2(a)) with a number of endotherms and one exotherm. The sharp exotherm is the $\alpha \rightarrow \beta$ phase transition of quartz that is used as a reference point. TG analysis (Fig. 2(b)) shows that there is initially a sharp drop of mass ( 4\%) up to $\sim 100-150^{\circ} \mathrm{C}$ which is the loss of interlayer water, continuing much more slowly up to $400^{\circ} \mathrm{C}$. Then another significant mass drop, commencing at $450^{\circ} \mathrm{C}$ is observed, with two distinct steps, corresponding to the dehydroxylation process. There is no mass loss beyond $\sim 800^{\circ} \mathrm{C}$ stabilising at $\sim 91 \%$ of the initial value. There is good agreement of this mass loss with the loss on ignition of the clay up to $1000^{\circ} \mathrm{C}$ of $8.2 \%$ determined during chemical analysis which corresponds to the loss of water and hydroxyl species (Table 1). XRD patterns from selected samples are shown in Fig. 3. In the initial room temperature sample a set of broad, but nevertheless definite reflections are present. Such a pattern is typical of a clay and the pattern indexed in accordance with the patterns available in the crystallographic databases for illite (i.e. $\left.\mathrm{K}_{1.5} \mathrm{Al}_{4}\left(\mathrm{Si}_{6.5} \mathrm{Al}_{1.5}\right) \mathrm{O}_{20}(\mathrm{OH})_{4}\right)$. After heating to $1000^{\circ} \mathrm{C}$ some very weak reflections are observed which are difficult to assign and there are some very broad features from the glass present. Then heating to $1600^{\circ} \mathrm{C}$ the crystalline reflections have narrowed considerably, and can be assigned as a mixture of mullite and $\alpha-\mathrm{Al}_{2} \mathrm{O}_{3}$. There is still some broad underlying intensity from the glass that remains in the sample.

${ }^{29}$ Si MAS NMR spectra are shown in figure 4 from all the samples, including the initial clay at room temperature and those heated from 200 to $1600^{\circ} \mathrm{C}$, with the peak positions and linewidths summarised in Table 2 . At $\leq 400^{\circ} \mathrm{C}$, the spectra remain effectively unchanged showing two resolved peaks at -86.8 and $-92.0 \mathrm{ppm}$, and a small shoulder at $-82.9 \mathrm{ppm}$ (see Table 2). The parameters for the peaks were deduced by fitting three Gaussian lines. Above $400^{\circ} \mathrm{C}$, heating up to $900^{\circ} \mathrm{C}$, there are only some minor changes in the spectrum with the clear resolution of the two main peaks being lost and a small shift of the peak (peak position and width, Table 2). Between 
900 and $1000^{\circ} \mathrm{C}$ the ${ }^{29} \mathrm{Si}$ MAS NMR spectrum undergoes a very significant change, with the peak shifting to $-100 \mathrm{ppm}$ and the resonance getting very much broader. From 1000 to $1600^{\circ} \mathrm{C}$ only small, but nevertheless distinct changes occur. The main broad resonance starts at $-101 \mathrm{ppm}$, but shifts progressively to $-95.9 \mathrm{ppm}$ at $1600^{\circ} \mathrm{C}$. At $1200^{\circ} \mathrm{C}$ there is also a small, sharper peak that appears at $\sim-86 \mathrm{ppm}$. This small peak increases in intensity with increasing heat treatment, although it becomes less resolved as the main broader resonance moves to more positive shift.

The corresponding ${ }^{27} \mathrm{Al}$ MAS NMR spectra collected at $18.8 \mathrm{~T}$ are shown in Fig. 5 and are described here in terms of their peak positions (Table 2) with the actual isotropic chemical shifts given in Table 3. As with the ${ }^{29} \mathrm{Si}$ data no significant change is observed in the spectra of samples heated to $\leq 400^{\circ} \mathrm{C}$ with two resolvable peaks present, a smaller one at $70 \mathrm{ppm}$ (Table 2) corresponding to $\mathrm{AlO}_{4}$ and the major peak at $4.4 \mathrm{ppm}$ assigned to $\mathrm{AlO}_{6}$. Then at $650^{\circ} \mathrm{C}$ some noticeable changes start to occur with both the initial resonances broadening. The $\mathrm{AlO}_{6}$ signal in particular develops a distinctive tail to negative shift. There is also some evidence of an additional resonance at intermediate shifts ( $25 \mathrm{ppm}$, Table 2). Above $600^{\circ} \mathrm{C}$, the $\mathrm{AlO}_{6}$ peak continues to decrease in intensity until $900^{\circ} \mathrm{C}$, when the original sharp peak at $2.5 \mathrm{ppm}$ has very low intensity. The octahedral peak is replaced by $\mathrm{AlO}_{4}$ and $\mathrm{AlO}_{5}$ signals, and also a much broader $\mathrm{AlO}_{6}$ resonance. At $1000^{\circ} \mathrm{C}$ there is a marked change in the spectrum with the $\mathrm{AlO}_{6}$ region now showing two $\mathrm{AlO}_{6}$ resonances at 12 and $4 \mathrm{ppm}$. The $\mathrm{AlO}_{5}$ peak completely disappears and there is a profound change in the $\mathrm{AlO}_{4}$ peak. The $\mathrm{AlO}_{4}$ peak changes both its shape and shows a significant shift of $\sim 10 \mathrm{ppm}$. Then with increasing heat treatment temperature the fraction of $\mathrm{AlO}_{4}$ increases and there is changing intensity between the two $\mathrm{AlO}_{6}$ resonances observed, until at

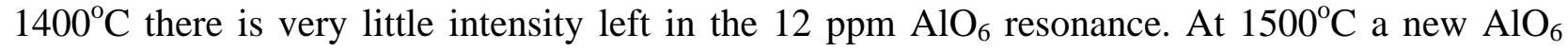
resonance appears at $14.9 \mathrm{ppm}$ which increases in intensity on heating up to $1600^{\circ} \mathrm{C}$.

By carrying out the experiment at $18.8 \mathrm{~T}$, the high magnetic field reduces second-order quadrupole effects [37] so that in some cases better resolution can be observed than at $14.1 \mathrm{~T}$, for 
example, between the different $\mathrm{AlO}_{6}$ resonances seen in samples heated in the range 1000 to $1400^{\circ} \mathrm{C}$. When the lineshapes from quadrupole nuclei do not show well defined second-order quadrupolar features, such as singularities, unambiguous simulation of the lineshape is difficult, especially if the data is obtained at only one magnetic field. Taking data at a second magnetic field allows more definite lineshape analysis. The spectra have been simulated using a programme QuadFit assuming second-order quadrupolar lineshapes including a distribution of the interaction parameters. A simple Gaussian distribution of the quadrupolar coupling constant about a mean value is taken along with an additional Gaussian broadening representing a chemical shift distribution $(\Delta)$. The parameters are iterated between the two fields until a single set of parameters (that include the isotropic chemical shift $\left(\delta_{\text {iso }}\right)$, the quadrupole coupling constant $\left(\chi_{\mathrm{Q}}\right)$ and the width of the distribution in the quadrupole interaction $\left(\Delta \chi_{Q}\right)$ and the additional Gaussian broadening $(\Delta)$ ) are arrived at that gives the best simulation at both fields [38]. Some examples of typical simulations are shown in Fig. 6. The NMR interaction parameters derived from the two field simulation are given in Table 3. In samples from the unheated one to that heated to $400^{\circ} \mathrm{C}$ the spectra are essentially identical, with $\sim 28 \pm 3 \%$ of the aluminium present as $\mathrm{AlO}_{4}$. The simulations are of the centrebands so that with finite spinning speeds that amount of intensity will depend on the factor $\left(\chi_{\mathrm{Q}}{ }^{2} / v_{0} v_{\mathrm{r}}\right)$ where $v_{\mathrm{o}}$ is the Larmor frequency and $v_{\mathrm{r}}$ is the spinning speed $[11,39]$. There is only $4 \%$ difference in this factor between the two sets of conditions used here. To get the true intensity distribution between the different sites the simulated intensity needs to be corrected to account for the fraction of intensity that appears in the centreband $[11,39]$. However for most sites $\left(\chi_{\mathrm{Q}}<7.5 \mathrm{MHz}\right)$ this correction is smaller than the 3\% error estimated in the simulation and even for the largest value of $\chi_{\mathrm{Q}}$ of $10 \mathrm{MHz}$ because of the high fields and quite fast spinning employed here $92 \%$ of the intensity still appears in the centreband simulation and so any correction will only be small. 
At $400^{\circ} \mathrm{C}$ there is still not really any change, e.g. in the aluminium distribution, but there are some signs of precursors of change in that there is a slight increase in the quadrupole coupling constant $\left(\chi_{Q}\right)$. After heating to $650^{\circ} \mathrm{C}$ the spectrum begins to change more rapidly as the $\mathrm{AlO}_{6^{-}}$ content starts to drop as dehydroxylation occurs. The strong overlap between the two $\mathrm{AlO}_{4}$ signals means that there is probably a larger degree of error in their parameters, but nevertheless it is clear that there are two $\mathrm{AlO}_{4}$ species. The effect of the high field providing extra resolution can be seen from there being a clear shoulder on the $\mathrm{AlO}_{4}$ signal. The $\mathrm{AlO}_{5}$ site that is formed only has a moderate $\chi_{\mathrm{Q}}$ but has a much larger broadening that scales with the magnetic field, indicative of the chemical shift distribution being dominant. At $900^{\circ} \mathrm{C}$ when the structure is beginning to significantly breakdown there is a large distortion of some of the environments. At $1000^{\circ} \mathrm{C}$ there is a large change in the spectrum as the $\mathrm{AlO}_{5}$ is completely lost. There are definitely two $\mathrm{AlO}_{6}$ sites, with the main $\mathrm{AlO}_{6}$ site, which is presumably from a transitional alumina/spinel component, having a large field gradient with a distribution showing that this site has a large variation in parameters throughout the sample. There are two $\mathrm{AlO}_{4}$ sites, with the site at $\sim 60 \mathrm{ppm}$ probably from the aluminosilicate glass. At $1200^{\circ} \mathrm{C}$ only a single $\mathrm{AlO}_{4}$ site is distinguishable. The mulliterelated $\mathrm{AlO}_{6}$ site remains with similar parameters, but above $1400^{\circ} \mathrm{C}$ a new $\mathrm{AlO}_{6}$ peak appears with a shift $\sim 17$ ppm that increases in intensity with heat treatment temperature.

The proton MAS NMR spectra (Fig. 7) show that there are two distinct resonances in the initial clay at 4.9 and $2.0 \mathrm{ppm}$. Neither of these two resonances has strong sidebands. There is some sign oftwo peaks persisting even after significant heat treatment, but the higher shift (4.9-4.6 ppm) peak decreases in both peak amplitude and shift, and is probably completely lost at $750^{\circ} \mathrm{C}$. The $2.0 \mathrm{ppm}$ peak persists up to $900^{\circ} \mathrm{C}$, while at higher temperatures still a very much broader, weak peak is observed with a shift of $\sim 3.7 \mathrm{ppm}$. The absolute intensity of the proton signal was also deduced by comparing the integrated signal from a weighed adamantane standard. The normalised proton intensity (in mol per g) are shown in Fig. 8. It can be seen that the proton- 
content remains very approximately constant up to $\sim 400^{\circ} \mathrm{C}$ and the spectra do not really change, although the peak at $\sim 4.9 \mathrm{ppm}$ does get a bit broader than at lower heat treatment temperatures so that the resolution is worse. There is no increase in the absolute intensity of the $2.0 \mathrm{ppm}$ peak within the accuracy of the measurements. From $400^{\circ} \mathrm{C}$ there is a decrease in the overall intensity with increased heat treatment, up to $\sim 800^{\circ} \mathrm{C}$, after which the proton-content remains approximately steady at only $~ 5 \%$ of the original level.

${ }^{39} \mathrm{~K}$ static NMR spectra are shown in Fig. 9. In the initial clay there is a well defined single resonance at $-41 \mathrm{ppm}$, with good signal to noise obtained even though the potassium-content is only $\sim 3.6 a t \%$. The lineshape shows some asymmetry to negative shift. There is no real change up to $900^{\circ} \mathrm{C}$ with the peak position remaining approximately constant and a small increase in the linewidth up to this point. After heating at $1000^{\circ} \mathrm{C}$ although the peak position does not really change, remaining at $\sim-50 \mathrm{ppm}$, the resonance has become much broader. With further heat treatment the width of the spectra becomes slowly greater and increasingly asymmetric.

\section{Discussion}

In heating a clay the main reactions that occur initially are the loss of protons both as water from the interlayer space that is hydrating the cations, and from the hydroxyls of the gibbsite layer. It would appear from the absolute signal intensity that there is very little proton signal loss up to $400^{\circ} \mathrm{C}$, but TG analysis shows a $4 \%$ mass loss up to $\sim 400^{\circ} \mathrm{C}$. The difference between thermal analysis and NMR experiments is that the samples for the ${ }^{1} \mathrm{H}$ MAS NMR spectra have been cooled back to room temperature and the water can re-enter the system, whereas the thermal analysis is of course carried out at temperature. The high shift signal at $\sim 4.9 \mathrm{ppm}$ gets broader and changes shift (Table 4) suggesting that this is associated with the water, and as it is interacts again with the potassium it appears less ordered than in the sample prior to any heat treatment. The other peak at $2.0 \mathrm{ppm}$ corresponds to the hydroxyls which is in good agreement with the shift 
determined for hydroxyls in kaolinite at $2.8 \mathrm{ppm}$ [40]. Then at higher temperatures this peak gets much weaker as the process is no longer reversible. The significant loss of proton signal intensity, effectively starting at $\sim 400^{\circ} \mathrm{C}$ and carrying on up to $\sim 800^{\circ} \mathrm{C}$ is associated with the dehydroxylation of the gibbsite layer. Finally there is a very broad proton peak remaining even at $>1000^{\circ} \mathrm{C}$. This is a very weak signal of only $\sim 5 \%$ of the initial intensity and is probably only the surface interacting proton-species that are almost always present on the surfaces of such aluminosilicates.

It is clear from both the ${ }^{29} \mathrm{Si}$ and ${ }^{27} \mathrm{Al}$ NMR that below $400^{\circ} \mathrm{C}$ the dehydration process which occurs in the interlayer space has no affect on the environments in the silica and gibbsite layers. The ${ }^{27} \mathrm{Al}$ MAS NMR spectra show that as expected most of the aluminium is present as $\mathrm{AlO}_{6}$ from the gibbsite layers. There is some $\mathrm{AlO}_{4}$ that corresponds to substitution in the silica layer. The $\mathrm{AlO}_{6}: \mathrm{AlO}_{4}$ ratio determined experimentally of $2.6 \pm 0.1$ agrees well with the ratio expected for the ideal illite composition of 2.7. The aluminium substitution in the silica layer conveys a negative charge to these layers and is charge balanced by the interlayer potassium. In the unfired clay the ${ }^{29}$ Si MAS NMR spectra reveal a silicon shift characteristic of $\mathrm{Q}^{3}$ sites. For layer aluminosilicates such as illites and closely related clay minerals such as muscovite resolution of different sites is often limited as the presence of iron greatly degrades the resolution of such ${ }^{29}$ Si MAS NMR spectra. In Lode for instance [31] there were hints of at least two distinct silicon sites. For other closely related micaceous minerals resolution of different $\mathrm{Q}^{3}$ silicon sites have sometimes been observed [41]. These different sites are usually attributed to a single crystallographic distinct silicon site in the layer with varying numbers of next nearest neighbour (nnn) aluminiums. The three ${ }^{29} \mathrm{Si}$ resonances observed here can therefore be assigned as $\mathrm{Q}^{3}(0 \mathrm{Al})$, $\mathrm{Q}^{3}(1 \mathrm{Al})$ and $\mathrm{Q}^{3}(2 \mathrm{Al})$ to the peaks at $-92.0,-86.8$ and $-82.9 \mathrm{ppm}$ respectively [41]. The relative intensities of these lines obtained from fitting the spectrum are $60 \pm 4 \%, 35 \pm 4 \%$ and $5 \pm 2 \%$. Various models have been advanced for the dispersion of the aluminium within such aluminosilicate sheets. Lowenstein's rule means that direct Al-O-Al bonding is avoided. It has been found that 
there is a tendency for the dispersion to be stronger than this, various studies indicating a homogeneous dispersion within the layer usually gives a better description [42,43]. Comparing the relative intensity of the three species observed in the spectrum, Lowenstein's rule would give $45 \%$ $\mathrm{Q}^{3}(0 \mathrm{Al}), 41 \% \mathrm{Q}^{3}(1 \mathrm{Al})$ and $12 \% \mathrm{Q}^{3}(2 \mathrm{Al})$, while a homogeneous distribution would give $54 \%$ $\mathrm{Q}^{3}(0 \mathrm{Al}), 40 \% \mathrm{Q}^{3}(1 \mathrm{Al})$, and $5 \% \mathrm{Q}^{3}(2 \mathrm{Al})$. It is clear from the intensity distribution determined from the illite studied here that the aluminium distribution much more closely matches the homogeneous model than that from Lowenstein's rule.

After heating to $650^{\circ} \mathrm{C}$, small but definite changes commence in the layer structure, most noticeably for the aluminium sites where there is a small broadening of the $\mathrm{AlO}_{6}$ site, but the most noticeable difference is the formation of some $\mathrm{AlO}_{5}(\sim 14 \%)$. The $\mathrm{AlO}_{4}$ resonance broadens and shows a shift. The $650^{\circ} \mathrm{C}$ data taken at $18.8 \mathrm{~T}$ is quite revealing in that the $\mathrm{AlO}_{4}$ region shows definite structure, probably as a result of contributions from both aluminium still residing in the silica layer and that forming as dehydroxylation occurs. The ${ }^{29}$ Si MAS NMR spectrum shows only minor changes with a slight decrease of shift and increase in broadening so that the two main sites can no longer be clearly resolved. This probably comes about as the silica layer distorts slightly as the adjacent gibbsite layer starts to dehydroxylate. It is clear from the samples heated up to $800^{\circ} \mathrm{C}$ that the peak position changes from $\sim-89$ to $\sim-93$ ppm. There is no reason to suppose at these temperatures the aluminium-content of this layer is changing. For aluminosilicates there is generally observed to be a decrease of the isotropic ${ }^{29} \mathrm{Si}$ chemical shift with an increase in the average Si-O-Si bond angle [11]. Hence a more negative ${ }^{29} \mathrm{Si}$ chemical shift may indicate that as the adjacent gibbsite layer dehydroxylates and starts to separate the average Si-O-Si bond angle increases. Then, with continued heating up to $900^{\circ} \mathrm{C}$ the silicate layer shows little further change in both its peak position and broadening. The ${ }^{27} \mathrm{Al}$ MAS NMR spectra always show some $\mathrm{AlO}_{5}$ in the same temperature range, and increasing $\mathrm{AlO}_{4}$ as the $\mathrm{AlO}_{6}$-content decreases as dehydroxylation proceeds, reducing the coordination of the gibbsite layer. It is interesting to 
compare the development of $\mathrm{AlO}_{5}$ here with that formed in related clay phases. Calcium montmorillonite shows a small amount of $\mathrm{AlO}_{5}$ [30], with none present in Lode [31], indicating that there is great variation in the stability of $\mathrm{AlO}_{5}$ in these intermediate, disordered phases formed from illite-related clay minerals. In pyrophyllite all aluminium becomes $\mathrm{AlO}_{5}$ in the intermediate state [26]. One of the reasons that has been advanced for this difference is the nature of the cations in the structure; Lode's main cation is $\mathrm{K}^{+}$and for Fuller's Earth (montmorillonite) it is $\mathrm{Ca}^{2+}$, while no cations are found in pyrophyllite. However potassium is also present in the illite studied here and there is a definite $\mathrm{AlO}_{5}$ signal. Hence the results reported here indicate that the effects of the nature of the interlayer cation are at most weak. It could be that the lack of $\mathrm{AlO}_{5}$ signal in Lode is that the iron present is closely associated with the $\mathrm{AlO}_{5}$ that wipes out this signal from the NMR spectrum. This data suggests that it is now more likely that other possible reasons that have been advanced for differences between the amount of intermediate $\mathrm{AlO}_{5}$ formation are more likely. For example the amount of intermediate $\mathrm{AlO}_{5}$ formation could be determined by whether the hydroxyls in the octahedral layer are either cis-cis or cis-trans oriented, where cis has O-Al-OH and trans $\mathrm{OH}-\mathrm{Al}-\mathrm{OH}$ configurations and this varies between different illites [44].

At $1000^{\circ} \mathrm{C}$ very significant changes occur in the spectra. For example, the silicon moves from a shift of $-92 \mathrm{ppm}$, typical of a $\mathrm{Q}^{3}$ peak, to $-101 \mathrm{ppm}$ in the $\mathrm{Q}^{4}$ chemical shift range. This is indicative of the silica layer now becoming a connected three-dimensional network. The ${ }^{29} \mathrm{Si}$ NMR peak has also significantly broadened, indicating that the new silica-based phase forming is much more structurally disordered than the initial layer. ${ }^{27} \mathrm{Al}$ MAS NMR also shows large changes in heating from 900 to $1000^{\circ} \mathrm{C}$. The $\mathrm{AlO}_{5}$-content drops rapidly and the $\mathrm{AlO}_{4}$ changes peak position from 65 to $55 \mathrm{ppm}$. There are two distinct $\mathrm{AlO}_{6}$ sites, both showing a significant tail, indicating a large distribution of quadrupole interactions, although the spectrum is dominated by the tail from the peak with an isotropic chemical shift of $18.8 \mathrm{ppm}$. The large changes in both the ${ }^{29} \mathrm{Si}$ and ${ }^{27} \mathrm{Al}$ MAS NMR spectra are indicative of large structural changes that are occurring at 
this point. Thermal analysis shows a broad endothermic event from $\sim 900-1100^{\circ} \mathrm{C}$, which is probably due to the layers forming three-dimensional nanodomains and silica-based layer forming a glass. The changes in the ${ }^{29} \mathrm{Si}$ chemical shift and the formation of the $\mathrm{AlO}_{4}$ peak at $52 \mathrm{ppm}$ are both consistent with formation of an aluminosilicate glass. Potassium in the interlayer space experiences some electric field gradient as indicated by the linewidth and asymmetry of the peak. As the aluminosilicate glass forms, the potassium shows significant broadening, probably an indication that potassium is taken up by the aluminosilicate glass, and in the glass potassium experiences a much larger electric field gradient.

It is interesting to compare these results with those from other illite-rich clays such as Lode [31] and Silver Hill [32]. After glass formation the ${ }^{27} \mathrm{Al}$ MAS NMR spectra from these samples showed a peak at $~ 52 \mathrm{ppm}$, indicating that all the aluminium became tetrahedrally coordinated. The difficulty with these previous NMR studies of these clays was the largely unknown effect of the iron-content, especially with respect to the differential loss of signal from different phases as the iron present does not partition equally between them. In the current illite, where interpretation is not hampered by signal loss through paramagnetic broadening, there is certainly significant $\mathrm{AlO}_{6}$ content. There are two $\mathrm{AlO}_{6}$ peaks, one of which at $4 \mathrm{ppm}$ is probably from mullite. This mullite formation appears to occur before the $1200^{\circ} \mathrm{C}$ found for halloysite [25] and kaolinite [16, 20, 22]. However there is certainly another $\mathrm{AlO}_{6}$-containing phase which could be a $\gamma$-alumina or spinel based phase present in this illite at these temperatures corresponding to the peak at 12 ppm. Both the shift and $\chi_{\mathrm{Q}}$ of the peak at $\sim 12 \mathrm{ppm}$ are characteristic of a transitional alumina $[12,45,46]$.

Then with more heating, further, but more subtle changes occur with the main peak in the silicon spectrum shifting from -101 at $1000^{\circ} \mathrm{C}$ to $-95 \mathrm{ppm}$ at $1600^{\circ} \mathrm{C}$. The $\mathrm{AlO}_{6}$ peak at $\sim 4 \mathrm{ppm}$ gets more intense while that at $12 \mathrm{ppm}$ decreases. A new peak at $15 \mathrm{ppm}$ grows after heating above $1400^{\circ} \mathrm{C}$. These changes can be explained by the potassium aluminosilicate glass phase 
being present throughout this temperature range, but is gradually changing its composition, dissolving more aluminium as the heat treatment temperature is increased. The evidence for this is that the average ${ }^{29} \mathrm{Si}$ isotropic chemical shift decreases, consistent with increasing numbers of aluminium next nearest neighbours, and the amount of $\mathrm{AlO}_{4}$ in the ${ }^{27} \mathrm{Al}$ MAS NMR spectra increases. The accepted overall illite formula $\left(\mathrm{K}_{1.5} \mathrm{Al}_{4}\left(\mathrm{Si}_{6.5} \mathrm{Al}_{1.5}\right) \mathrm{O}_{20}(\mathrm{OH})_{4}\right)$ is in very good agreement with the chemical composition quoted in Table 1. Hence as the silica-based layers form the initial potassium aluminosilicate glass, the $\mathrm{Si}$ :Al atomic ratio is likely to be $\mathrm{Si}_{6.5} \mathrm{Al}_{1.5}$ charge balanced with $\mathrm{K}_{1.5}$. Based on this ratio of metals and simply scaling to reflect the formulae of the common oxide components gives a chemical composition of $\mathrm{K}_{2} \mathrm{O} \cdot \mathrm{Al}_{2} \mathrm{O}_{3} \cdot 8 \cdot 6 \mathrm{SiO}_{2}$. The eutectic composition in this region of the phase diagram corresponds to $\mathrm{K}_{2} \mathrm{O} \cdot \mathrm{Al}_{2} \mathrm{O}_{3} \cdot 11.2 \mathrm{SiO}_{2}$ with glass of this composition first appearing at $990 \pm 20^{\circ} \mathrm{C}[47,48]$. Then the temperature dependence of the liquid phase boundary is such that the silica-content of the liquid phase decreasing until at $\sim 1100^{\circ} \mathrm{C}$ the liquid phase should then match that of the initial layer composition (i.e. $\mathrm{K}_{2} \mathrm{O} \cdot \mathrm{Al}_{2} \mathrm{O}_{3} \cdot 8 \cdot 6 \mathrm{SiO}_{2}$ ). At higher temperatures still the liquid should also have this composition, but is in contact with an aluminium-rich phase so it is plausible that a further increase in the aluminium-content might occur. Hence the glassy phase that initially forms can be expected to be more silica-rich than the average layer composition. As it is heated to higher temperatures the phase diagram tie lines to the liquid phase indicate an increasing aluminium-content. Hence the observed trends in the ${ }^{29} \mathrm{Si}$ chemical shift can be rationalised in terms of the expected changing composition of the glass.

The ${ }^{29}$ Si MAS NMR spectrum from the sample heated to $1200^{\circ} \mathrm{C}$ shows the small, sharp peak at $-86 \mathrm{ppm}$ that is partially resolved from the main glass resonance. This probably corresponds to crystallisation of mullite, indicated by the small, sharp endothermic event at $\sim 1200^{\circ} \mathrm{C}$. At this point in the ${ }^{29} \mathrm{Si}$ MAS NMR spectrum there is the appearance of a small sharp peak at -86 ppm that comes from mullite. . The ${ }^{27} \mathrm{Al}$ MAS NMR spectra also show formation of an additional aluminous phase above $1400^{\circ} \mathrm{C}$. XRD is dominated by mullite with some $\alpha-\mathrm{Al}_{2} \mathrm{O}_{3}$, 
the latter agreeing with the 15 ppm peak, and the glass component of the sample does not show up strongly in the XRD. There is an interesting comparison of the ${ }^{27} \mathrm{Al}$ NMR interaction parameters that have been determined for the phases here and those that have appeared previously in the literature. Mullite has at least three distinct aluminium sites, one $\mathrm{AlO}_{6}$ and two $\mathrm{AlO}_{4}$, with one of the $\mathrm{AlO}_{4}$ having an unusual isotropic chemical shift at $53 \mathrm{ppm}$ from tetrahedra joined as triclusters [49,50]. Detailed spectral simulations using satellite transition spectroscopy showed 3 different $\mathrm{AlO}_{4}$ sites, with the $\mathrm{AlO}_{6}: \mathrm{AlO}_{4}$ ratio 45:55. Considering the mullite in the sample heated to $1600^{\circ} \mathrm{C}$, from the intensity observed in the $\mathrm{AlO}_{6}$ centreband associated with the mullite, this could mean that up to $\sim 20 \%$ of the $\mathrm{AlO}_{4}$ in these ${ }^{27} \mathrm{Al}$ NMR spectra could be from the mullite, although mullites with much lower $\mathrm{AlO}_{4}$-content can occur [25]. However no $\mathrm{AlO}_{4}$ site from the mullite can be distinguished from the main $\mathrm{AlO}_{4}$ from the glass in the 1D MAS NMR spectra. The shifts of the $2 \mathrm{AlO}_{6}$ sites at 17.1 and $8.9 \mathrm{ppm}$ agree, within the errors, to the known values for $\alpha-\mathrm{Al}_{2} \mathrm{O}_{3}$ and mullite respectively. However the quadrupole coupling constants $\alpha-\mathrm{Al}_{2} \mathrm{O}_{3} \chi_{\mathrm{Q}}$ is $\sim 2$ larger than well crystallised, single phase samples [45]. This is probably a result of it still being effectively nanocrystalline and reflected in the local sites being more distorted. For the $\mathrm{AlO}_{6}$ in mullite there is excellent agreement between the $\chi_{\mathrm{Q}}$ from the simulation and the estimate made from the linewidth both of which give $8.5 \mathrm{MHz}$, and there is reasonable agreement with the previous study of a mullite that gave $\chi_{\mathrm{Q}}$ of $7.3 \mathrm{MHz}$ [50]. For this site the lineshape has a very pronounced tail indicative of a significant spread of interaction parameters at these sites. Mullite is a solid solution $\mathrm{Al}_{2}\left(\mathrm{Al}_{2+2 \mathrm{x}} \mathrm{Si}_{2-2 \mathrm{x}}\right) \mathrm{O}_{10-\mathrm{x}}$ and there have been careful studies examining how the NMR parameters and occupancies of the different sites vary. For ${ }^{27} \mathrm{Al}$ the NMR parameters and the $\mathrm{AlO}_{4}: \mathrm{AlO}_{6}$ ratio vary with composition (x) $[51,52]$. Also the peak intensities of the different ${ }^{29}$ Si sites varies with the aluminium/vacancy composition of the sample [51,53,54]. Hence in principle if the ${ }^{29} \mathrm{Si}$ and ${ }^{27} \mathrm{Al}$ MAS NMR spectra can be accurately simulated more details about the nature of the mullite and any changes with heat treatment would be revealed. The problem here is that the mullite is 
occurring with at least two other phases with significant spectral overlap that precludes sufficient accuracy to allow this approach to be followed.

The multinuclear NMR data presented here reveal some key details of the structural breakdown of this illite. In comparing the breakdown of illite to other clays there are some points in common and clear differences. The silica and gibbsite layers to some extent behave somewhat independently as the sample is heated. As dehydroxylation occurs the average aluminium coordination is reduced, as a mixture of $\mathrm{AlO}_{5}$ and $\mathrm{AlO}_{4}$ form from $\mathrm{AlO}_{6}$. The amount of $\mathrm{AlO}_{5}$ that forms is intermediate to that seen in other clay minerals. Effectively the layers start to form separate phases. When the silica layer starts to form a separate aluminosilicate glass it dissolves the interlayer potassium ions. From the amorphous dehydroxylated alumina phase a mixture of other aluminous phases, probably spinel/transitional alumina and mullite form. Then at higher temperatures some atomic intermixing occurs, with the glass phase probably increasing its aluminium-content. Although not well resolved, which makes accurate deconvolution difficult, there is certainly a ${ }^{29} \mathrm{Si}$ peak at $\sim 86 \mathrm{ppm}$, that appears to increase with increasing heat treatment For chemically simpler clays such as halloysite the mullite phase initially formed is alumina-rich and its silicon-content increases at higher temperatures [25]. It may be that the same thing happens here. The resolution observed here in the ${ }^{29}$ Si MAS NMR spectra, has shown for the first time in an illite that the glass composition probably varies with heat treatment, consistent with increasing $\mathrm{AlO}_{4}$-content of the sample. The assignments and suggestions made here for the thermal breakdown of this very low iron-content illitic clay could be further tested by multiresonance NMR experiments such as ${ }^{1} \mathrm{H}-{ }^{29} \mathrm{Si}$ cross-polarisation and correlation, and multiple quantum and satellite transition MAS of ${ }^{27} \mathrm{Al}$. However, this paper illustrates the ability of multinuclear one dimensional MAS NMR to give insight into the atomic scale structural rearrangements that occur in the thermal decomposition of a clay. 


\section{Conclusion}

This report of multinuclear solid state NMR from a very low iron-content illitic clay has provided atomic scale insight into the structural rearrangements that occur in this group of clays as they are heated. It improves on previous work on such clay minerals through the study of 4 separate nuclei, and the fact that complications resulting from differential signal loss due to paramagnetic iron is removed. The NMR complements bulk thermal and powder XRD analysis. Loss of interlayer water has little effect on the clay layers and is largely reversible, although the ${ }^{1} \mathrm{H}$ peak assigned to this water does shift on thermal cycling. Once hydroxyls start to come off from the gibbsite layer the associated formation of lower coordination aluminium species (both $\mathrm{AlO}_{4}$ and $\mathrm{AlO}_{5}$ ) is observed, with continued heating producing slightly more $\mathrm{AlO}_{5}$, but considerably more $\mathrm{AlO}_{4}$. As the gibbsite layer dehydroxylates there are only small corresponding changes in the neighbouring silica layers. After dehydroxylation the major structural event occurs between 900 and $1000^{\circ} \mathrm{C}$ where the silica layer forms an aluminosilicate glass that contains the potassium ions. At the same point alumina-rich mullite and spinel $/ \gamma-\mathrm{Al}_{2} \mathrm{O}_{3}$ form. A common theme observed in all clays to date studied in detail by solid state NMR is that at the point where the remnant two-dimensional layer structure is lost the silica and gibbsite layers form essentially separate three-dimensional nanodomain structures, although they are intimately mixed. The data collected here also suggests that the glass subsequently changes composition with heat treatment, dissolving more aluminium. At $1600^{\circ} \mathrm{C}$ the sample contains a mixture of potassium aluminosilicate glass, mullite and probably $\alpha-\mathrm{Al}_{2} \mathrm{O}_{3}$, although for the crystalline samples the quadrupole interactions and the spread of values suggest that the local structure remains quite distorted even after significant heating. Insight is clearly provided by MAS NMR studies, such that thermal processing of these industrially important materials can be better understood. 


\section{Acknowledgements}

The EPSRC and University of Warwick are thanked for funding NMR equipment, the Nuffield Foundation is thanked for providing a summer bursary to D.L. Carroll and the Leverhulme Trust for providing a visiting professorship to T.J. Bastow. S. Certoks, R. Svinka and V. Svinka, Riga Technical University are thanked for provision of the sample and an accurate chemical analysis.

\section{References}

[1] G.W. Brindley, M. Nakahira, J. Am. Ceram. Soc. 42 (1959) 311.

[2] G.W. Brindley, J. Lemaitre, Chemistry of Clays and Clay Minerals, Longman, Harlow, 1990.

[3] W.E. Worrall, Clays and Ceramic Raw Materials, Elsevier Applied Science, Barking, 1986.

[4] R. E. Grim, R. H. Bray, W. F. Bradley, Am. Mineral. 22 (1937) 813.

[5] W.A. Deer, R.A. Howie, J. Zussman, An Introduction to the Rock-Forming Minerals. Longman Group, Hong Kong 1992.

[6] C.M. Earnest, Lecture Notes in Earth Sciences, Springer-Verlag Berlin, (1991) 270.

[7] R.E. Grim, W.F. Bradley, J. Am. Ceram. Soc. 22 (1940) 242.

[8] P.J. Michael, W.R. McWhinnie Polyhedron 8 (1989) 2709.

[9] E. Murad, U. Wagner, Clay Minerals 31 (1996) 45.

[10] G. Engelhardt, D. Michel, High Resolution Solid-State NMR of Silicates and Zeolites. John Wiley and Sons. Chichester (1987).

[11] K.J.D. MacKenzie, M.E. Smith, Multinuclear Solid State NMR of Inorganic Materials, Pergamon, Oxford, (2002).

[12] M.E. Smith, Appl. Magn. Reson. 4 (1993) 1.

[13] D.E. Woessner, Am. Mineral. 74 (1989) 203.

[14] K.J.D. Mackenzie, I.W.M. Brown, R.H. Meinhold, M.E. Bowden, J. Am. Ceram. Soc. 68 (1985) 293.

[15] T. Watanabe, H. Shimizu, K. Nagasawa, A. Masuda, H. Saito, Clay Minerals 22 (1987) 37.

[16] J. Sanz, A. Madani, J.M. Serratosa, J.S. Moya, S. Aza, J. Am. Ceram. Soc. 71 (1988) C418.

[17] J.F. Lambert, W.S. Millman, J.J. Fripiat, J. Am. Chem. Soc. 111 (1989) 3517.

[18] J. Rocha, J. Klinowski, Phys. Chem. Minerals 17 (1990) 179.

[19] R.C.T. Slade, T.W. Davis, J. Mater. Chem. 1 (1991) 361.

[20] D. Massiot, P. Dion, J. Alcover, F. Bergaya, J. Am. Ceram. Soc. 78 (1995) 2940.

[21] K.J.D. Mackenzie, J.S. Hartman, K. Okada, J. Am. Ceram. Soc. 79 (1996) 2980.

[22] P.A. Schroeder, R.J. Pruett, Am. Mineral. 81 (1996) 26.

[23] J. Rocha, J. Phys. Chem. B 103 (1999) 9801.

[24] H.P. He, J.G. Guo, J.X. Zhu, C. Hu, Clay Minerals 38 (2003) 551.

[25] M.E. Smith, G.S. Neal, M.B. Trigg, J. Drennan, Appl. Magn. Reson. 4, (1993) 157.

[26] J.J. Fitzgerald, S.F. Dec, A.I. Hamza, Am. Mineral. 74 (1989) 1405.

[27] P.J. Sanchez-Soto, I. Sobrados, J. Sanz, J.L. Rodriguez, J. Am. Ceram. Soc. 76 (1993) 3024.

[28] J.J. Fitzgerald, A.I. Hamza, S.F. Dec, C.E. Bronnimann, J. Phys. Chem. 100 (1996) 17351.

[29] I.W.M. Brown, K.J.D. MacKenzie, R.H. Meinhold, J. Mater. Sci. 22 (1987) 3265. 
[30] S.R. Drachman, G.E. Roch, M.E. Smith, Solid State NMR 9 (1997) 257.

[31] G.E. Roch, M.E. Smith, S.R. Drachman, Clays and Clay Minerals 46 (1998) 694.

[32] C.J. McConville, G.E. Roch, W.E. Lee, M.E. Smith, CIMTEC 2002 "Science for New

Technology of Silicate Ceramics” (2003) 97.

[33] M.E. Smith, Ann. Rep. NMR Spectro. 43 (2000) 121.

[34] T.J. Bastow, J. Chem. Soc., Faraday Trans. 87 (1991) 2453.

[35] J.-F. Lambert, R. Prost, M.E. Smith, Clays and Clay Minerals 40 (1992) 253.

[36] A.C. Kunwar, G.L. Turner, E. Oldfield, J. Magn. Reson. 69 (1986) 124.

[37] M.E. Smith, E.R.H. van Eck, Prog. NMR Spectrosc. 34 (1999) 159.

[38] T.F. Kemp, MSc Thesis, University of Warwick (2004).

[39] D. Massiot, C. Bessada, J.P. Coutures, F. Taulelle, J. Magn. Reson. 90 (1990) 231.

[40] S. Hayashi, T. Ueda, K. Hamamizu, E. Akiba, J. Phys. Chem. 96 (1992) 10922.

[41] J. Sanz, J.M. Serratosa, J. Am. Chem. Soc. 106 (1984) 4790.

[42] C.P. Herrero, J. Sanz, J.M. Serratosa, J. Phys. Chem. 93 (1989) 4311.

[43] S.K. Lausen, H.Lindgreen, H.J. Jakobsen, N.C. Nielsen, Am. Mineral. 84 (1999) 1433

[44] V.A. Drits, G. Besson, F. Muller, Clays and Clay Minerals 43 (1995) 718.

[45] D. Freude, Encyclopedia of Analytical Chemistry, Ed. R.A. Meyer, John Wiley and Sons Ltd, Chichester, (2000) 12188.

[46] G. Kunath-Fandrei, T.J. Bastow, J.S. Hall, C. Jäger, M.E. Smith, J. Phys. Chem. 99 (1995) 15138.

[47] J.F. Schairer, N.L. Bowen, Bull. Soc. Geol. Finlande 20 (1947) 74

[48] J.S. Brown, in Phase Diagrams in Advanced Ceramics, Ed. A.M. Alper, p55 Academci Press, London, 1995.

[49] L.H. Merwin, A. Sebald, H. Rager, H. Schneider, Phys. Chem. Minerals 18 (1991) 47.

[50] G. Kunath-Fandrei, P. Rehak, S. Steuernagel, C. Jäger, Solid State NMR 3 (1994) 241.[51] I. Jaymes, A. Douy, D. Massiot, J.P. Coutures, J. Chim. Phys. PCB 92 (1995) 1851

[52] P. Rehak, G. Kunath-Fandrei, P. Losso, B. Hildmann, H. Schneider, C. Jäger, Am. Mineral. 83 (1998) 1266.

[53] T. Ban, K. Okada, J. Am. Ceram. Soc. 76 (1993) 2491.

[54] I. Jaymes, A. Douy, D. Massiot, J.P. Coutures, J. Non-Cryst. Solids 204 (1996) 125. 
Table 1. Chemical analysis of Hungarian White Illite

\begin{tabular}{cc}
\hline Component & Content (wt \%) \\
\hline $\mathrm{SiO}_{2}$ & 49.6 \\
$\mathrm{Al}_{2} \mathrm{O}_{3}$ & 33.0 \\
$\mathrm{CaO}$ & 1.6 \\
$\mathrm{Fe}_{2} \mathrm{O}_{3}$ & 0.4 \\
$\mathrm{~K}_{2} \mathrm{O}$ & 6.6 \\
Loss on ignition $\left(400^{\circ} \mathrm{C}\right)$ & 4.3 \\
Loss on ignition $\left(1000^{\circ} \mathrm{C}\right)$ & 3.9
\end{tabular}

Table 2. Summary of ${ }^{29} \mathrm{Si}$ MAS NMR linewidths and peak positions and ${ }^{27} \mathrm{Al}$ peak positions at 18.8 $\mathrm{T}$ from an Hungarian white illite heated at various temperatures up to $1600^{\circ} \mathrm{C}$.

\begin{tabular}{|c|c|c|c|}
\hline $\begin{array}{c}\text { Sample heat } \\
\text { treatment } \\
\text { temperature } /{ }^{\circ} \mathrm{C}\end{array}$ & $\begin{array}{l}{ }^{29} \text { Si Peak } \\
\text { position /ppm } \\
\pm 0.2 \mathrm{ppm}\end{array}$ & $\begin{array}{c}{ }^{29} \mathrm{Si} \mathrm{linewidth} \\
\mathrm{Hz}\end{array}$ & $\begin{array}{c}{ }^{27} \mathrm{Al} \text { Peak position } \\
/ \mathrm{ppm} \\
\pm 0.2 \mathrm{ppm}\end{array}$ \\
\hline $\mathrm{RT}$ & $\begin{array}{c}-82.9,-86.8 \\
-92.0\end{array}$ & $\begin{array}{c}170 \pm 20,310 \pm 25 \\
420 \pm 25\end{array}$ & $71.3,4.4$ \\
\hline 200 & $\begin{array}{c}-82.6,-86.8 \\
-92.1\end{array}$ & $\begin{array}{c}190 \pm 20,300 \pm 25 \\
450 \pm 25\end{array}$ & $70.8,4.5$ \\
\hline 400 & $\begin{array}{c}-82.5,-86.6 \\
-91.4\end{array}$ & $\begin{array}{c}210 \pm 20,300 \pm 25 \\
500 \pm 50\end{array}$ & 71.3, 4.3 \\
\hline 650 & -91.9 & $800 \pm 50$ & $66.5,27.4,3.9$ \\
\hline 700 & -92.6 & $700 \pm 50$ & $65.9,25.6,3.9$ \\
\hline 750 & -92.8 & $800 \pm 50$ & $65.0,24.3,3.2$ \\
\hline 800 & -92.6 & $900 \pm 50$ & $65.2,24.8,3.7$ \\
\hline 900 & -93.2 & $1000 \pm 100$ & 63.6, 24.3, 2.5 \\
\hline 1000 & -100.4 & $1400 \pm 100$ & $55.4,12.0,4.3$ \\
\hline 1100 & -101.3 & $1400 \pm 100$ & $55.4,11.8,4.2$ \\
\hline 1200 & -101.1 & $1200 \pm 100$ & 55.6. 12.0, 3.7 \\
\hline 1300 & -97.1 & $1400 \pm 100$ & $55.8,11.8,3.0$ \\
\hline 1400 & -95.8 & $1200 \pm 100$ & $55.8,14.9,3.1$ \\
\hline 1500 & -95.6 & $1400 \pm 100$ & $56.0,14.7,2.9$ \\
\hline 1600 & -95.9 & $1300 \pm 100$ & $54.6,14.4,2.3$ \\
\hline
\end{tabular}


Table 3. Summary of ${ }^{27} \mathrm{Al}$ NMR interaction parameters deduced by 2 field NMR data simulated using the QuadFit programme from an Hungarian white illite heated at various temperatures up to $1600^{\circ} \mathrm{C}$.

\begin{tabular}{|c|c|c|c|c|c|c|}
\hline $\begin{array}{l}\text { Heat treatment } \\
\text { temperature } \\
\left({ }^{\circ} \mathrm{C}\right)\end{array}$ & Peak & $\begin{array}{c}\delta_{\text {iso }}(\mathrm{ppm}) \\
\pm 0.2\end{array}$ & $\begin{array}{c}\chi_{\mathrm{Q}}(\mathrm{MHz}) \\
\pm 0.5\end{array}$ & $\begin{array}{c}\Delta \chi_{\mathrm{Q}}(\mathrm{MHz}) \\
\pm 0.5\end{array}$ & $\begin{array}{c}\Delta(\mathrm{Hz}) \\
\pm 20\end{array}$ & $\begin{array}{l}\% \\
\pm 3\end{array}$ \\
\hline $\mathrm{RT}$ & $\begin{array}{l}\mathrm{AlO}_{4}, 1 \\
\mathrm{AlO}_{6}, 1\end{array}$ & $\begin{array}{c}72.4 \\
6.0\end{array}$ & $\begin{array}{l}2.9 \\
3.7\end{array}$ & $\begin{array}{l}1.4 \\
2.2\end{array}$ & $\begin{array}{c}100 \\
70\end{array}$ & $\begin{array}{l}26 \\
74\end{array}$ \\
\hline $200^{\circ} \mathrm{C}$ & $\begin{array}{l}\mathrm{AlO}_{4}, 1 \\
\mathrm{AlO}_{6}, 1\end{array}$ & $\begin{array}{c}71.8 \\
5.6 \\
\end{array}$ & $\begin{array}{l}2.6 \\
4.0 \\
\end{array}$ & $\begin{array}{l}1.7 \\
2.0\end{array}$ & $\begin{array}{c}100 \\
80 \\
\end{array}$ & $\begin{array}{l}28 \\
72 \\
\end{array}$ \\
\hline $400^{\circ} \mathrm{C}$ & $\begin{array}{l}\mathrm{AlO}_{4}, 1 \\
\mathrm{AlO}_{6}, 1\end{array}$ & $\begin{array}{c}72.8 \\
5.5 \\
\end{array}$ & $\begin{array}{l}3.5 \\
4.0 \\
\end{array}$ & $\begin{array}{l}1.0 \\
3.0\end{array}$ & $\begin{array}{c}100 \\
60 \\
\end{array}$ & $\begin{array}{l}30 \\
70 \\
\end{array}$ \\
\hline $650^{\circ} \mathrm{C}$ & $\begin{array}{l}\mathrm{AlO}_{4}, 1 \\
\mathrm{AlO}_{4}, 2 \\
\mathrm{AlO}_{5}, 1 \\
\mathrm{AlO}_{6}, 1\end{array}$ & $\begin{array}{c}72.3 \\
68.8 \\
25.5 \\
4.9 \\
\end{array}$ & $\begin{array}{l}4.5 \\
5.0 \\
4.0 \\
3.5\end{array}$ & $\begin{array}{l}1.0 \\
1.0 \\
0.1 \\
4.0\end{array}$ & $\begin{array}{c}100 \\
120 \\
500^{*} \\
80\end{array}$ & $\begin{array}{l}14 \\
20 \\
14 \\
52\end{array}$ \\
\hline $750^{\circ} \mathrm{C}$ & $\begin{array}{l}\mathrm{AlO}_{4}, 1 \\
\mathrm{AlO}_{4}, 2 \\
\mathrm{AlO}_{5}, 1 \\
\mathrm{AlO}_{6}, 1\end{array}$ & $\begin{array}{c}71.9 \\
67.2 \\
24.8 \\
4.4 \\
\end{array}$ & $\begin{array}{l}4.0 \\
4.5 \\
4.0 \\
4.5\end{array}$ & $\begin{array}{l}1.0 \\
1.5 \\
0.1 \\
4.0\end{array}$ & $\begin{array}{c}100 \\
130 \\
500^{*} \\
70\end{array}$ & $\begin{array}{c}7 \\
34 \\
16 \\
43\end{array}$ \\
\hline $900^{\circ} \mathrm{C}$ & $\begin{array}{l}\mathrm{AlO}_{4}, 1 \\
\mathrm{AlO}_{4}, 2 \\
\mathrm{AlO}_{5}, 1 \\
\mathrm{AlO}_{6}, 1\end{array}$ & $\begin{array}{c}65.6 \\
63.5 \\
33.6 \\
7.0 \\
\end{array}$ & $\begin{array}{c}3.0 \\
8.0 \\
10.0 \\
7.0\end{array}$ & $\begin{array}{l}1.0 \\
3.0 \\
2.0 \\
2.0\end{array}$ & $\begin{array}{c}200 \\
250 * \\
250 * \\
50\end{array}$ & $\begin{array}{l}23 \\
40 \\
24 \\
13\end{array}$ \\
\hline $1000^{\circ} \mathrm{C}$ & $\begin{array}{l}\mathrm{AlO}_{4}, 1 \\
\mathrm{AlO}_{4}, 2 \\
\mathrm{AlO}_{6}, 2 \\
\mathrm{AlO}_{6}, 1\end{array}$ & $\begin{array}{c}68.5 \\
60.2 \\
18.8 \\
7.2\end{array}$ & $\begin{array}{l}4.0 \\
6.5 \\
9.0 \\
6.0\end{array}$ & $\begin{array}{l}1.0 \\
2.0 \\
2.5 \\
1.5\end{array}$ & $\begin{array}{c}300 \\
250 * \\
150 \\
90\end{array}$ & $\begin{array}{c}11 \\
54 \\
12 \\
3\end{array}$ \\
\hline $1200^{\circ} \mathrm{C}$ & $\begin{array}{l}\mathrm{AlO}_{4}, 1 \\
\mathrm{AlO}_{4}, 2 \\
\mathrm{AlO}_{6}, 2 \\
\mathrm{AlO}_{6}, 1\end{array}$ & $\begin{array}{c}70.0 \\
59.8 \\
15.9 \\
9.8\end{array}$ & $\begin{array}{l}4.0 \\
5.5 \\
5.0 \\
9.0\end{array}$ & $\begin{array}{l}1.0 \\
2.0 \\
1.0 \\
2.0\end{array}$ & $\begin{array}{c}300 \\
300 * \\
230 \\
100 *\end{array}$ & $\begin{array}{c}8 \\
58 \\
12 \\
22\end{array}$ \\
\hline $1400^{\circ} \mathrm{C}$ & $\begin{array}{l}\mathrm{AlO}_{4}, 1 \\
\mathrm{AlO}_{6}, 2 \\
\mathrm{AlO}_{6}, 1\end{array}$ & $\begin{array}{l}59.7 \\
17.6 \\
10.0 \\
\end{array}$ & $\begin{array}{l}6.0 \\
4.0 \\
9.5 \\
\end{array}$ & $\begin{array}{l}3.0 \\
1.0 \\
2.2 \\
\end{array}$ & $\begin{array}{c}300 * \\
200 * \\
50 *\end{array}$ & $\begin{array}{c}71 \\
3 \\
27\end{array}$ \\
\hline $1600^{\circ} \mathrm{C}$ & $\begin{array}{l}\mathrm{AlO}_{4}, 1 \\
\mathrm{AlO}_{6}, 2 \\
\mathrm{AlO}_{6}, 1\end{array}$ & $\begin{array}{c}61.5 \\
17.1 \\
8.9\end{array}$ & $\begin{array}{l}6.5 \\
4.2 \\
8.5\end{array}$ & $\begin{array}{l}2.0 \\
1.2 \\
2.0\end{array}$ & $\begin{array}{c}300 * \\
90 \\
40\end{array}$ & $\begin{array}{l}71 \\
12 \\
17\end{array}$ \\
\hline
\end{tabular}

$\delta_{\text {iso }}$ is the isotropic chemical shift, $\chi_{\mathrm{Q}}$ is the quadrupole coupling constant ${ }^{37}, \Delta \chi_{\mathrm{Q}}$ is the width of the Gaussian distribution of quadrupole coupling constants, $\Delta$ is the additional Gauusian broadening employed, * these widths scaled approximately with the field and the value quoted is that used for the simulation at $14.1 \mathrm{~T}$. \% is the integrated intensity of the corresponding centreband. The asymmetry parameter of the quadrupole interaction is taken as zero. 
Table 4. Summary of ${ }^{1} \mathrm{H}$ MAS NMR peak positions from an Hungarian white illite heated at various temperatures up to $1100^{\circ} \mathrm{C}$.

\begin{tabular}{|c|c|}
\hline $\begin{array}{c}\text { Sample heat } \\
\text { treatment } \\
\text { temperature } /{ }^{\circ} \mathrm{C}\end{array}$ & $\begin{array}{c}{ }^{1} \mathrm{H} \text { peak } \\
\text { position } / \mathrm{ppm} \\
\pm 0.1 \mathrm{ppm}\end{array}$ \\
\hline $\mathrm{RT}$ & $4.9,2.0$ \\
200 & $4.8,2.1$ \\
400 & $4.6,2.2$ \\
600 & 2.1 \\
650 & 2.2 \\
700 & 2.0 \\
750 & 2.0 \\
800 & 1.8 \\
900 & $3.8,2.0$ \\
1000 & 3.5 \\
1100 & 4.2 \\
\hline
\end{tabular}

\section{Figure Captions}

Figure 1 Schematic structural picture of a 2:1 clay mineral such as illite.

Figure 2. (a) Differential scanning calorimetry and (b) thermogravimetric analysis from a white Hungarian illite heated at $10^{\circ} \mathrm{C} /$ minute in air.

Figure 3. XRD patterns from a Hungarian white illite clay at (a) room temperature, and after heating to (b) $1000^{\circ} \mathrm{C}$ and (c) $1600^{\circ} \mathrm{C}$.

Figure $4{ }^{29}$ Si MAS NMR spectra of a Hungarian white illite clay heated at various temperatures up to $1600^{\circ} \mathrm{C}$ for 2 hours.

Figure $5{ }^{27} \mathrm{Al}$ MAS NMR spectra of a Hungarian white illite clay heated at various temperatures up to $1600^{\circ} \mathrm{C}$ for 2 hours at a magnetic field of $18.8 \mathrm{~T}$. (* indicates spinning sidebands)

Figure 6 Examples of the simulation of the ${ }^{27} \mathrm{Al}$ MAS NMR spectra of a Hungarian white illite clay using the QuadFit programme for samples heated for 2 hours to $1600^{\circ} \mathrm{C}(\mathrm{A}, \mathrm{B}), 1000^{\circ} \mathrm{C}(\mathrm{C}, \mathrm{D})$ and $750^{\circ} \mathrm{C}(\mathrm{E}, \mathrm{F})$. Data was taken at $14.1 \mathrm{~T}(\mathrm{~A}, \mathrm{C}, \mathrm{E})$ and $18.8 \mathrm{~T}(\mathrm{~B}, \mathrm{D}, \mathrm{F})$ with each showing the separate components (lower), complete simulation (middle) and the experimental data (top)

Figure $7{ }^{1} \mathrm{H}$ MAS NMR spectra of a Hungarian white illite clay heated at various temperatures up to $1100^{\circ} \mathrm{C}$ for 2 hours.

Figure 8 The absolute proton-content of a Hungarian white illite clay heated at various temperatures up to $1100^{\circ} \mathrm{C}$ for 2 hours as deduced by quantitative proton NMR and corrected for probe background.

Figure $9{ }^{39} \mathrm{~K}$ static NMR spectra of a Hungarian white illite clay heated at various temperatures up to $1600^{\circ} \mathrm{C}$ for 2 hours. 
Figure 1 Schematic structural picture of a 2:1 clay mineral such as illite.

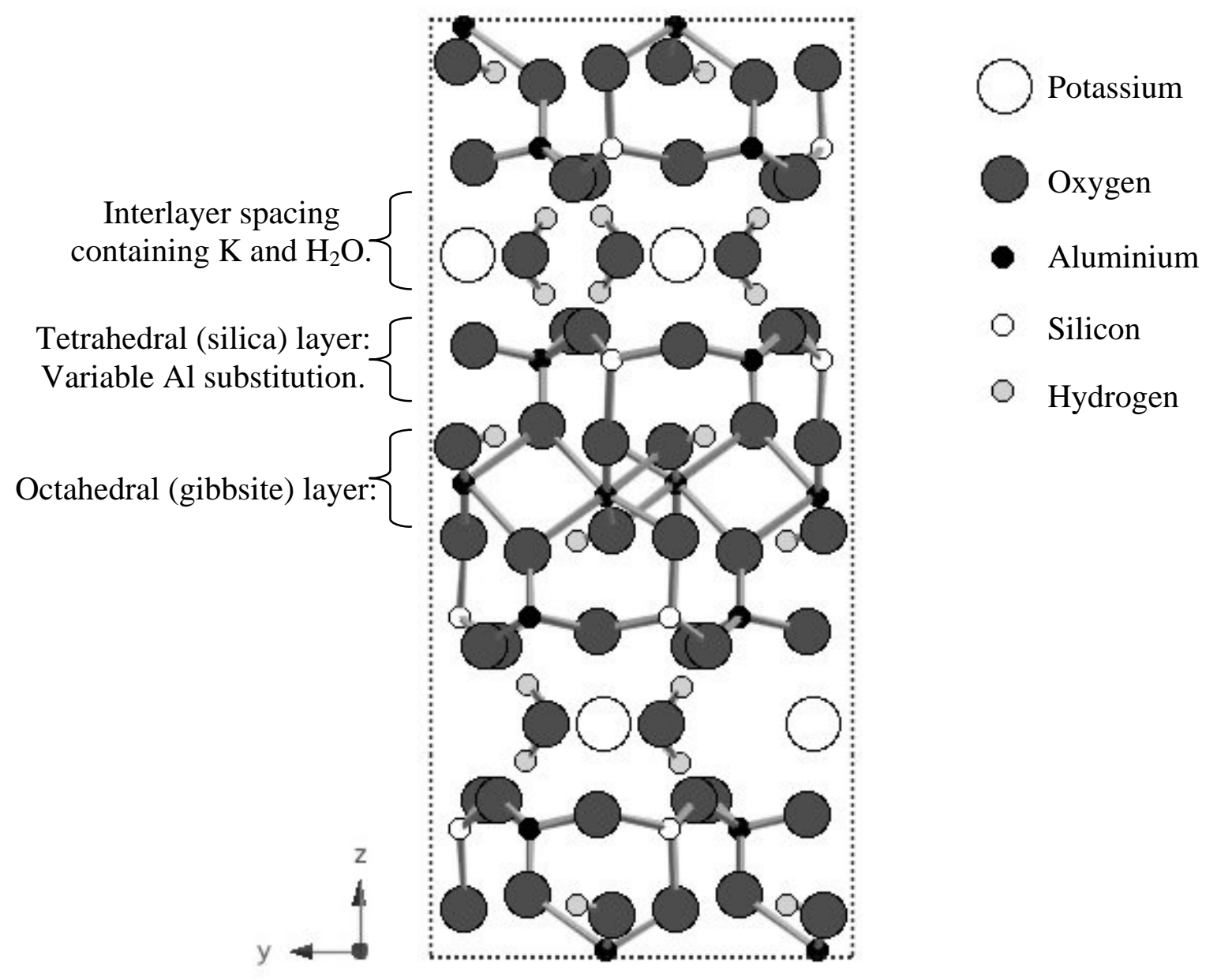


Figure 2. (a) Differential scanning calorimetry and (b) thermogravimetric analysis from a white Hungarian illite heated at $10^{\circ} \mathrm{C} /$ minute in air.

(a)

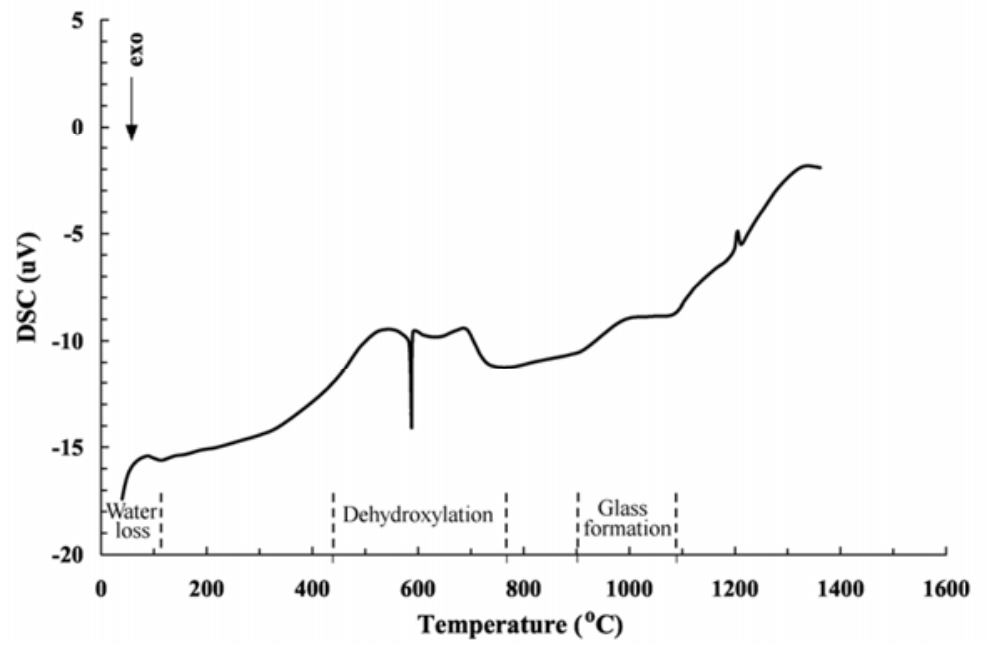

(b)

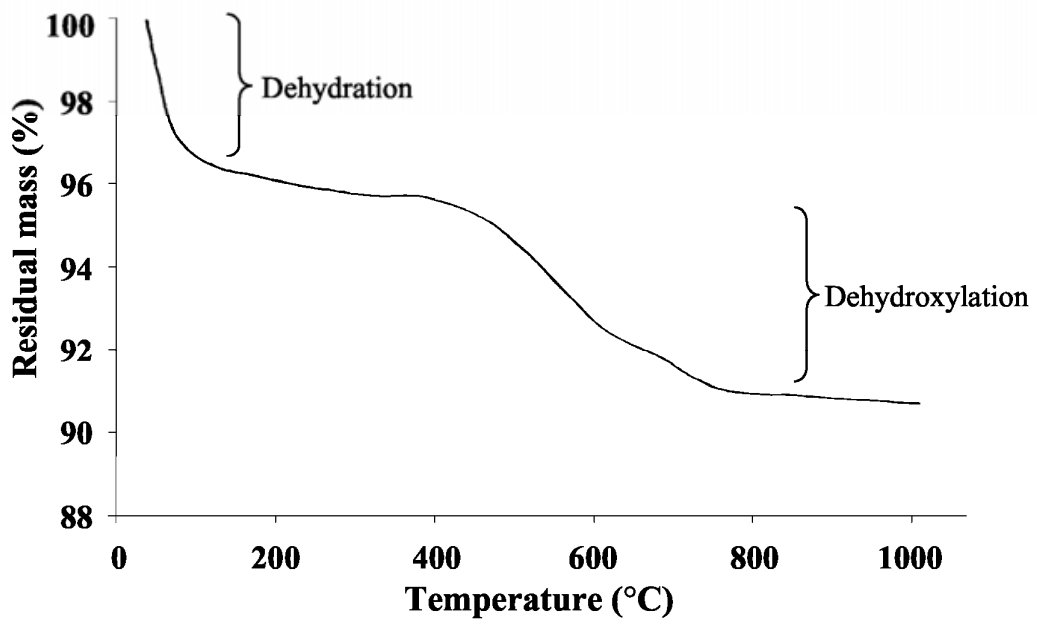


Figure 3 XRD patterns from a Hungarian white illite clay at (a) room temperature, and after heating to (b) $1000^{\circ} \mathrm{C}$ and (c) $1600^{\circ} \mathrm{C}$.

(a)

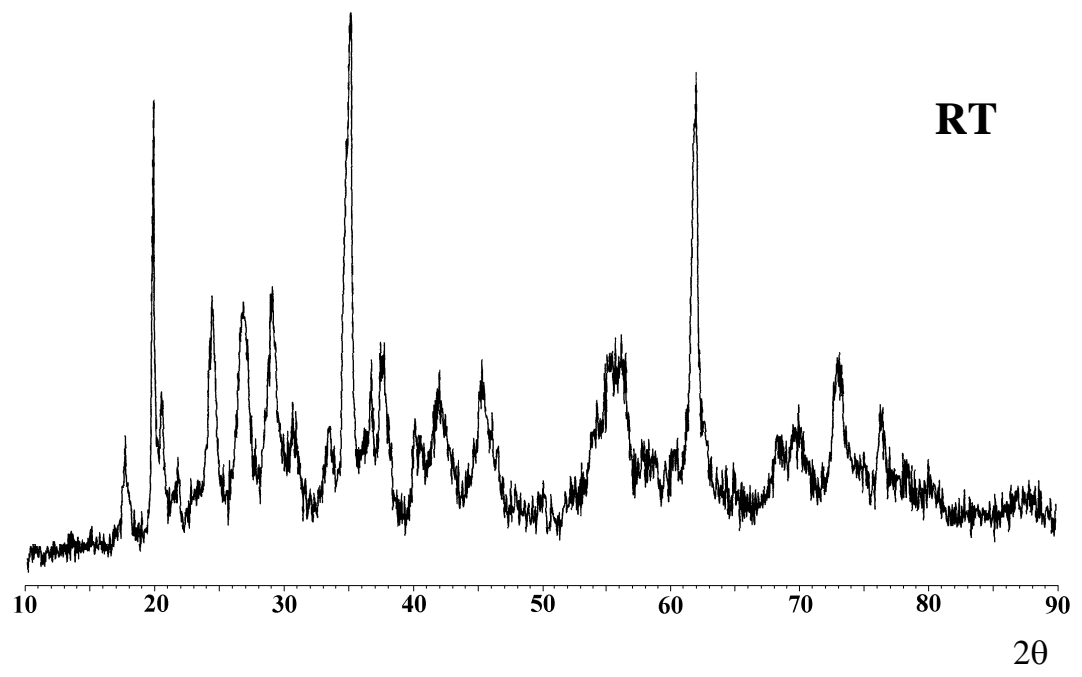

(b)
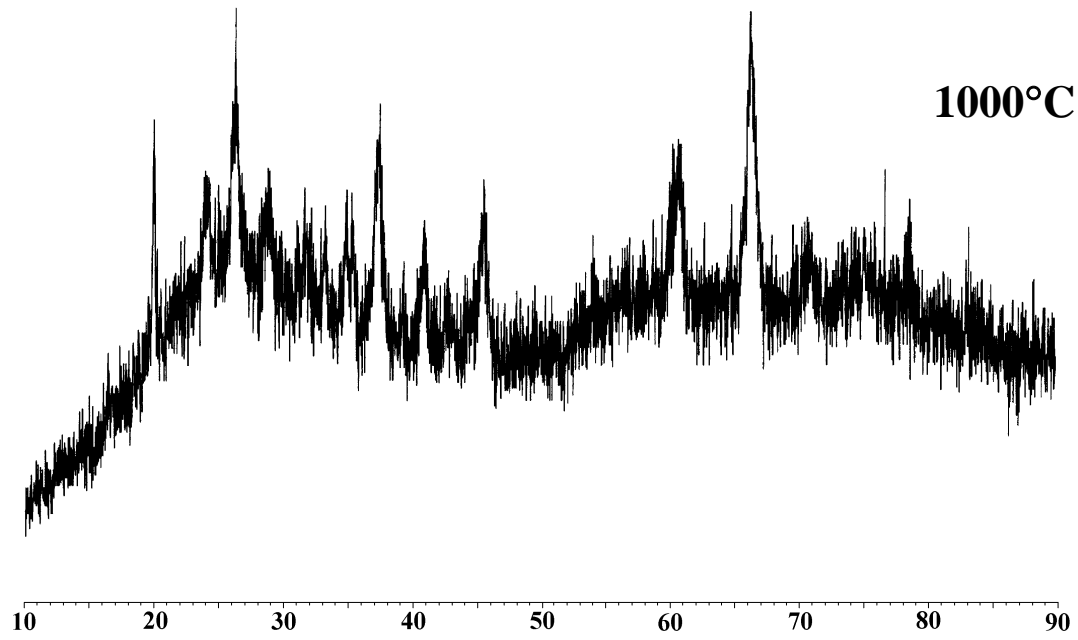

$2 \theta$

(c)

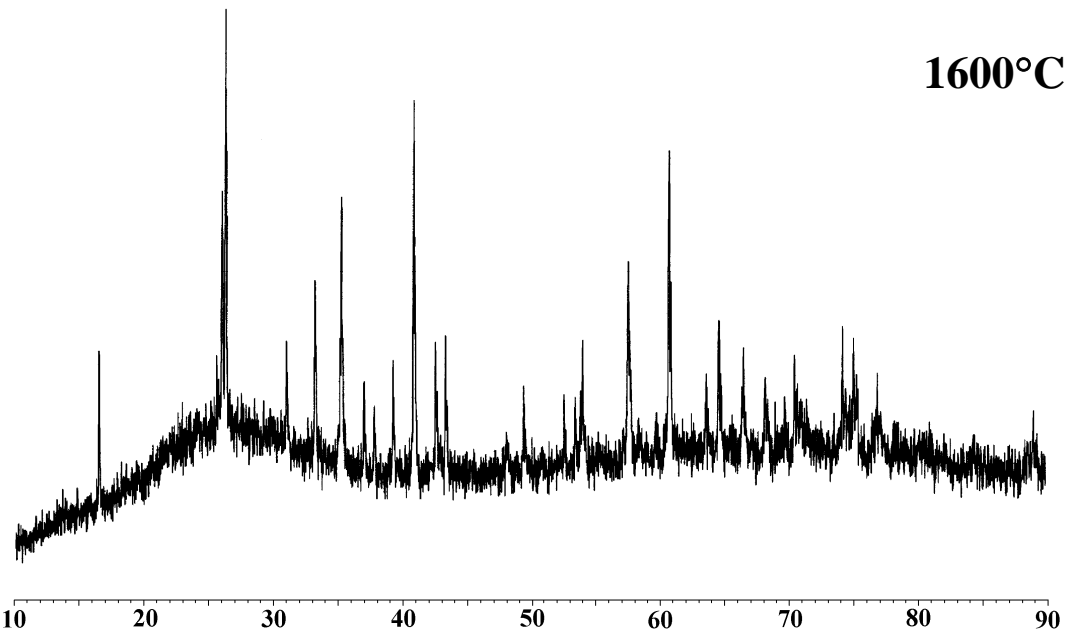


Figure $4{ }^{29} \mathrm{Si}$ MAS NMR spectra of a Hungarian white illite clay heated at various temperatures up to $1600^{\circ} \mathrm{C}$ for 2 hours.

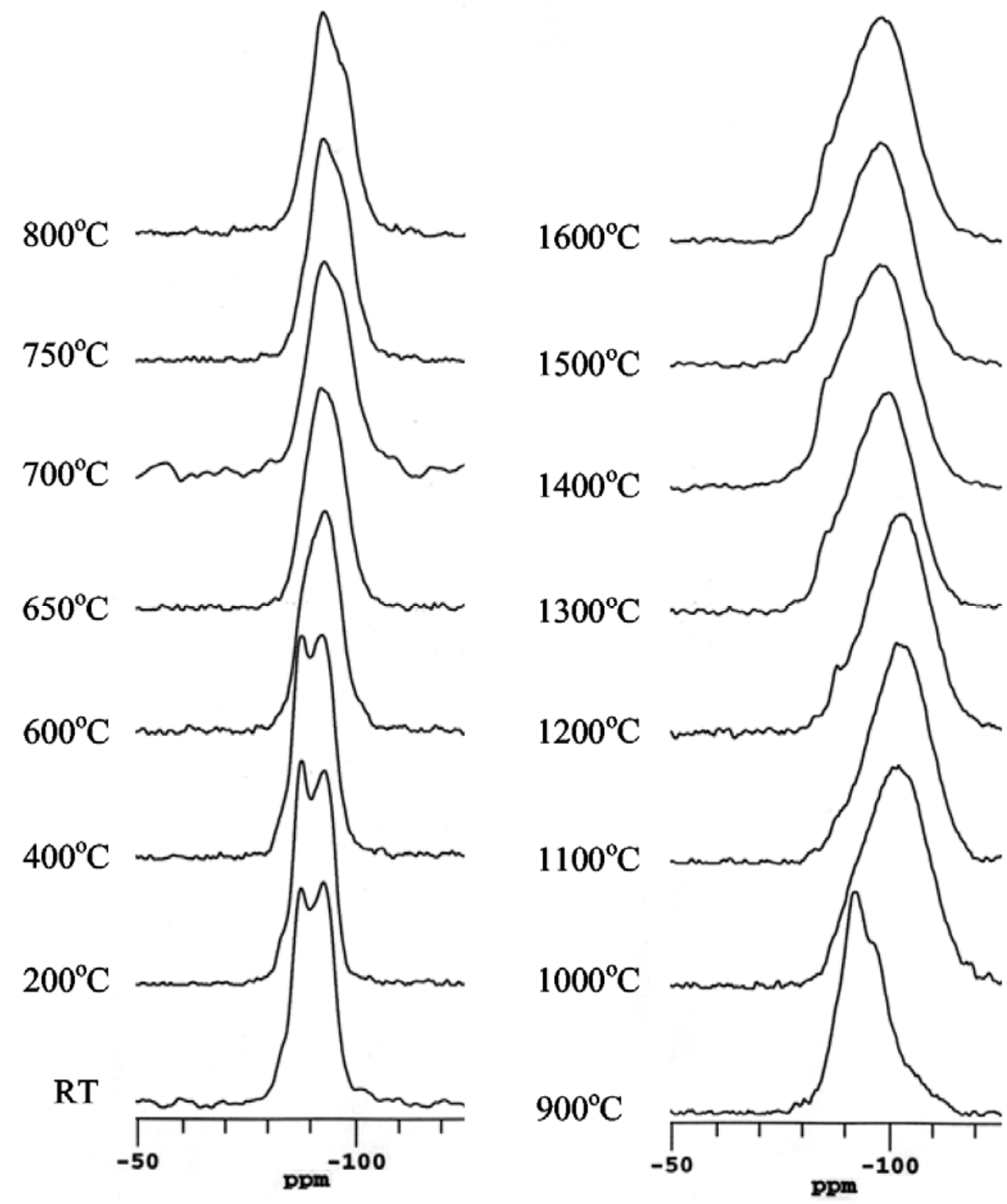


Figure $5{ }^{27} \mathrm{Al}$ MAS NMR spectra of a Hungarian white illite clay heated at various temperatures up to $1600^{\circ} \mathrm{C}$ for 2 hours at a magnetic field of $18.8 \mathrm{~T}$ (* indicates spinning sideband).
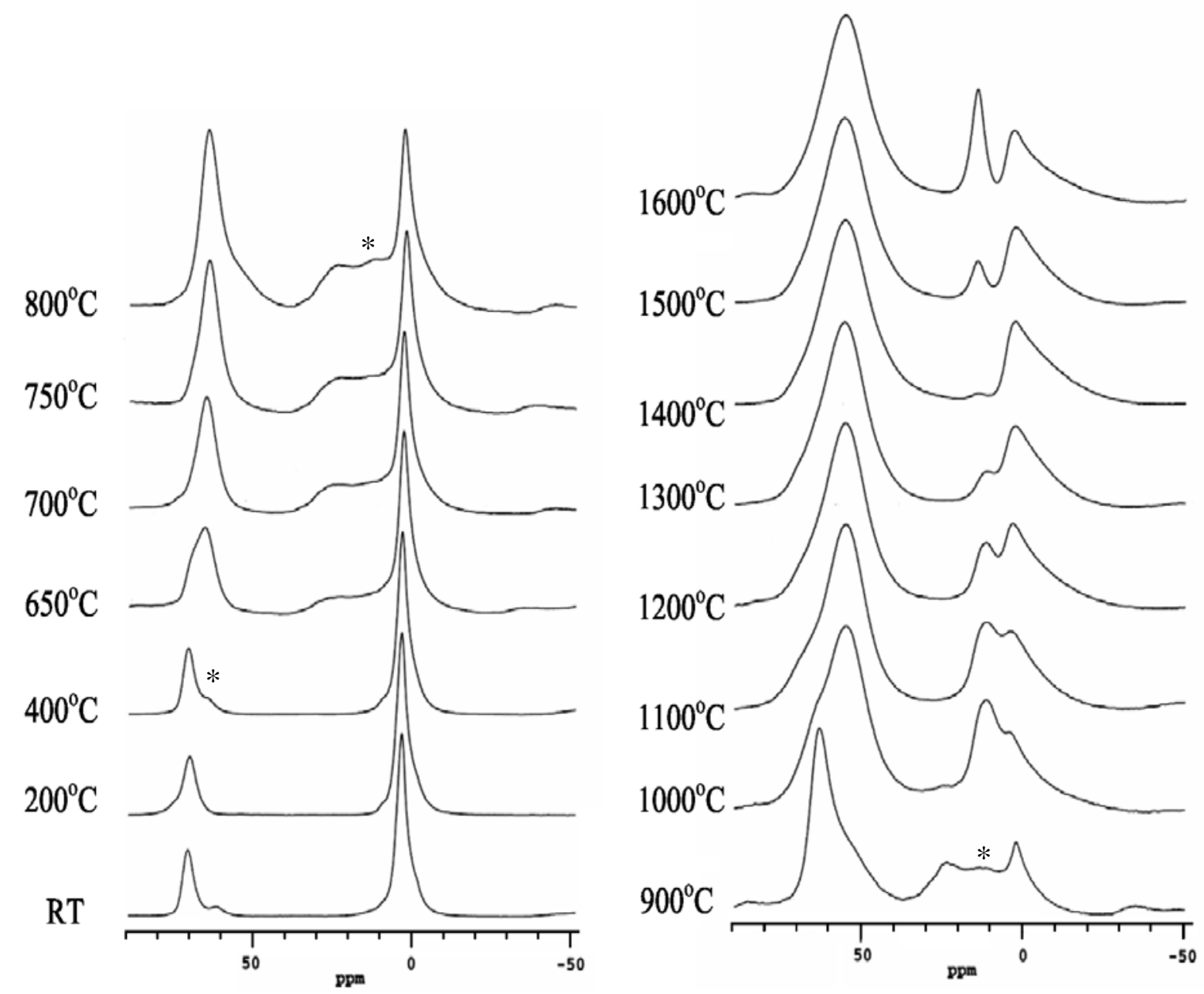
Figure 6 Examples of the simulation of the ${ }^{27} \mathrm{Al}$ MAS NMR spectra of a Hungarian white illite clay using the QuadFit programme for samples heated for 2 hours to $1600^{\circ} \mathrm{C}(\mathrm{A}, \mathrm{B}), 1000^{\circ} \mathrm{C}(\mathrm{C}, \mathrm{D})$ and $750^{\circ} \mathrm{C}(\mathrm{E}, \mathrm{F})$. Data was taken at $14.1 \mathrm{~T}(\mathrm{~A}, \mathrm{C}, \mathrm{E})$ and $18.8 \mathrm{~T}$ (B,D,F) with each showing the separate components (lower), complete simulation (middle) and the experimental data (top).
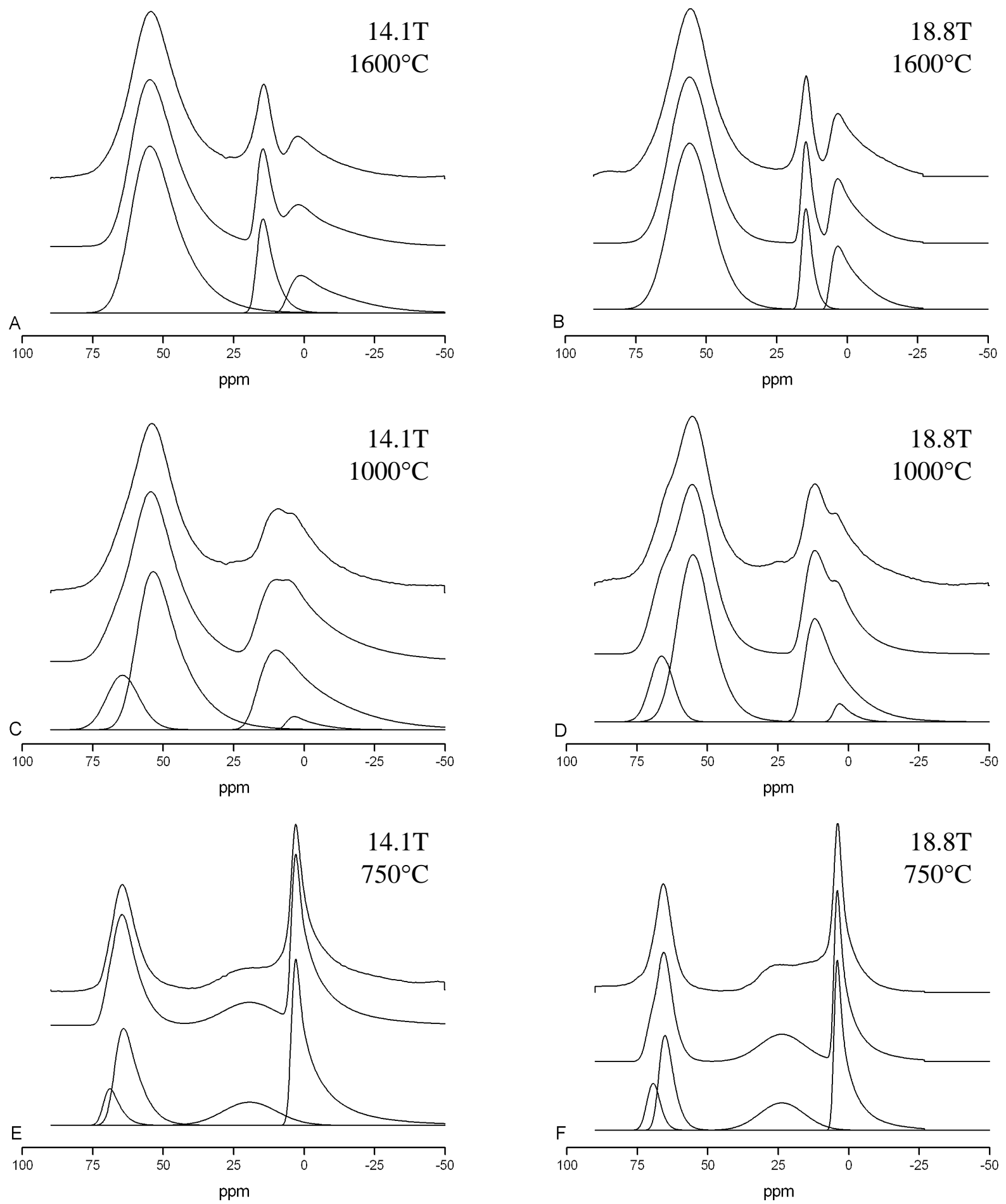
Figure $7{ }^{1} \mathrm{H}$ MAS NMR spectra of a Hungarian white illite clay heated at various temperatures up to $1100^{\circ} \mathrm{C}$ for 2 hours.

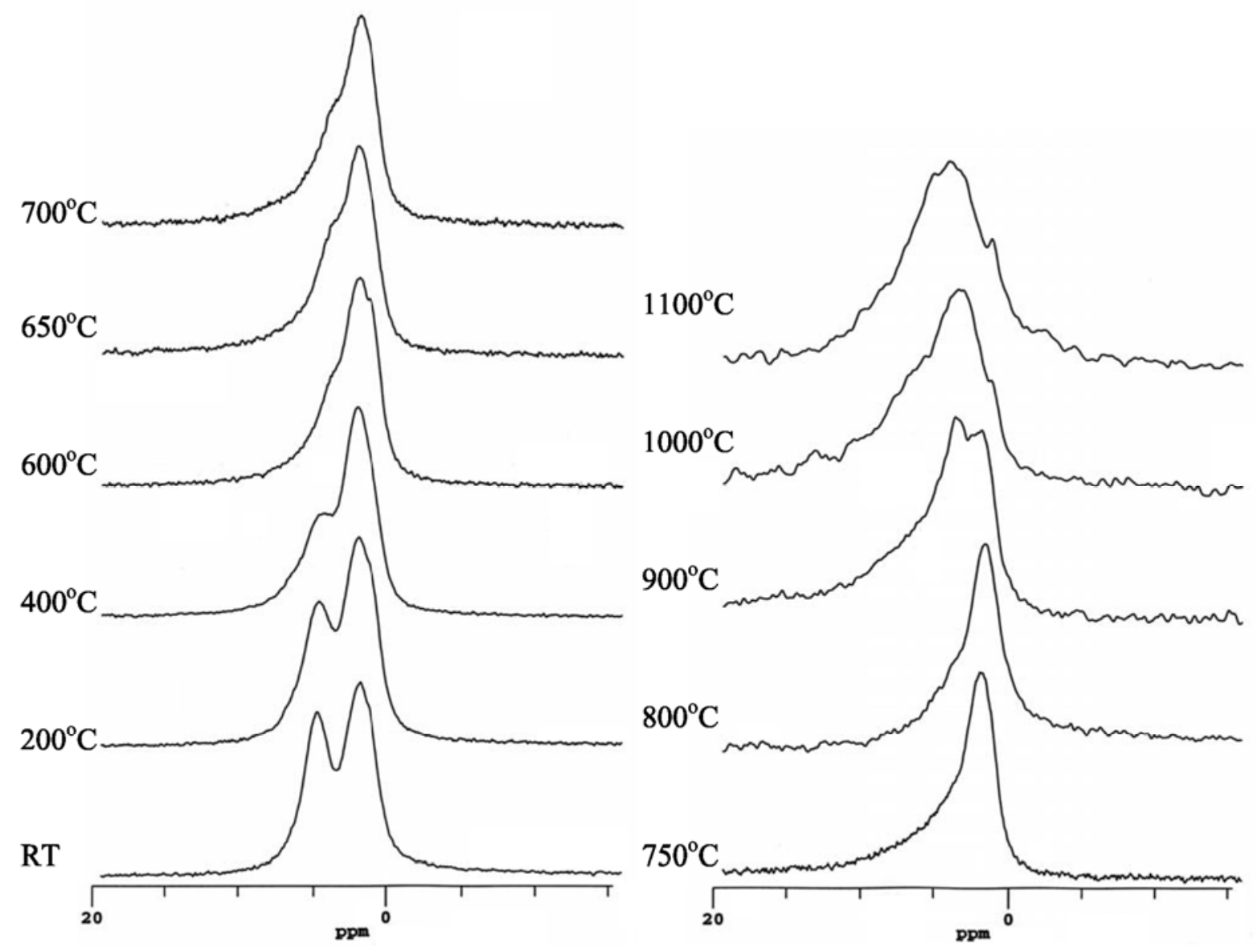


Figure 8 The absolute proton-content of a Hungarian white illite clay heated at various temperatures up to $1100^{\circ} \mathrm{C}$ for 2 hours as deduced by quantitative proton NMR and corrected for probe background.

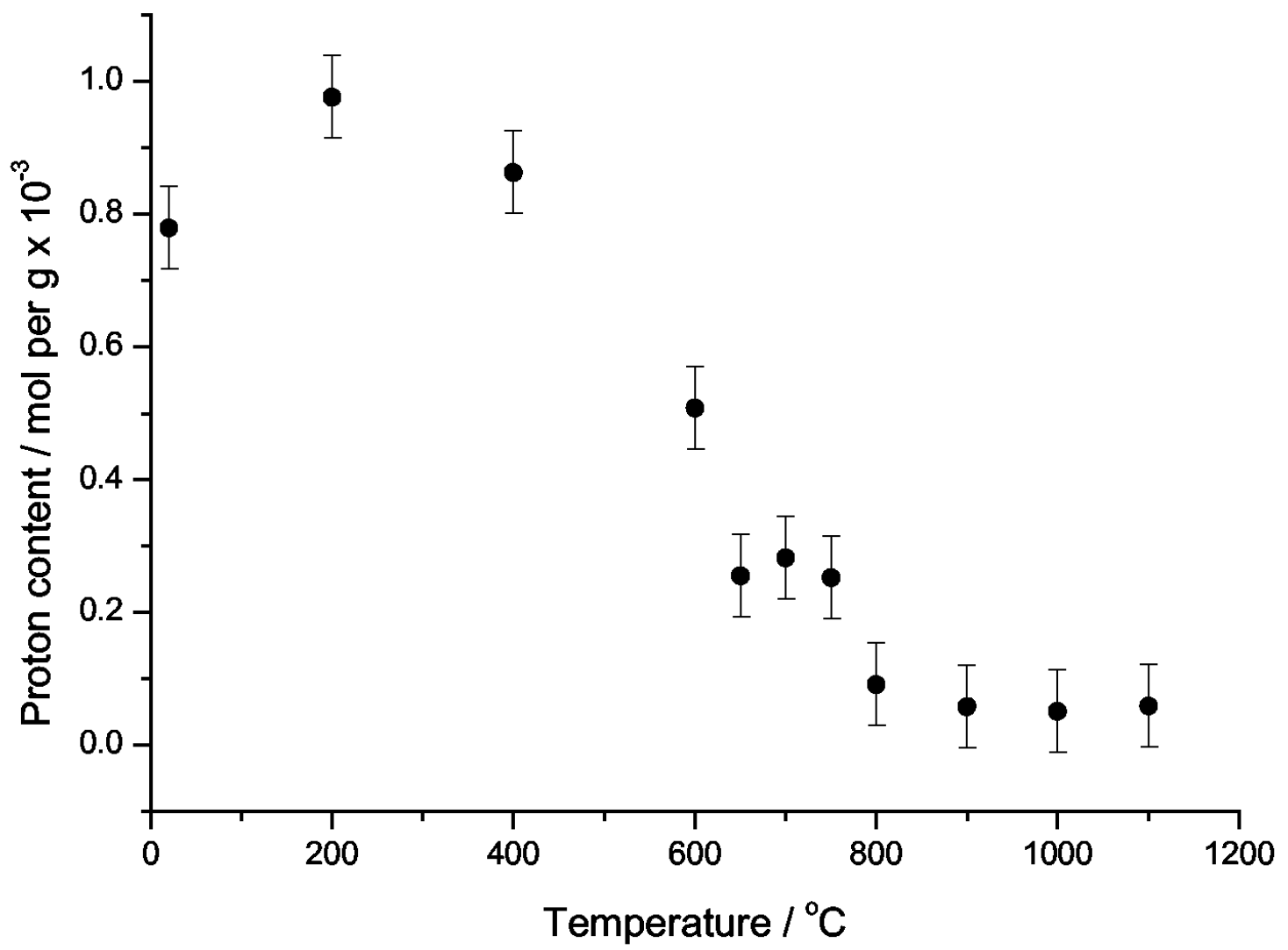


Figure $9{ }^{39} \mathrm{~K}$ static NMR spectra of a Hungarian white illite clay heated at various temperatures up to $1600^{\circ} \mathrm{C}$ for 2 hours.

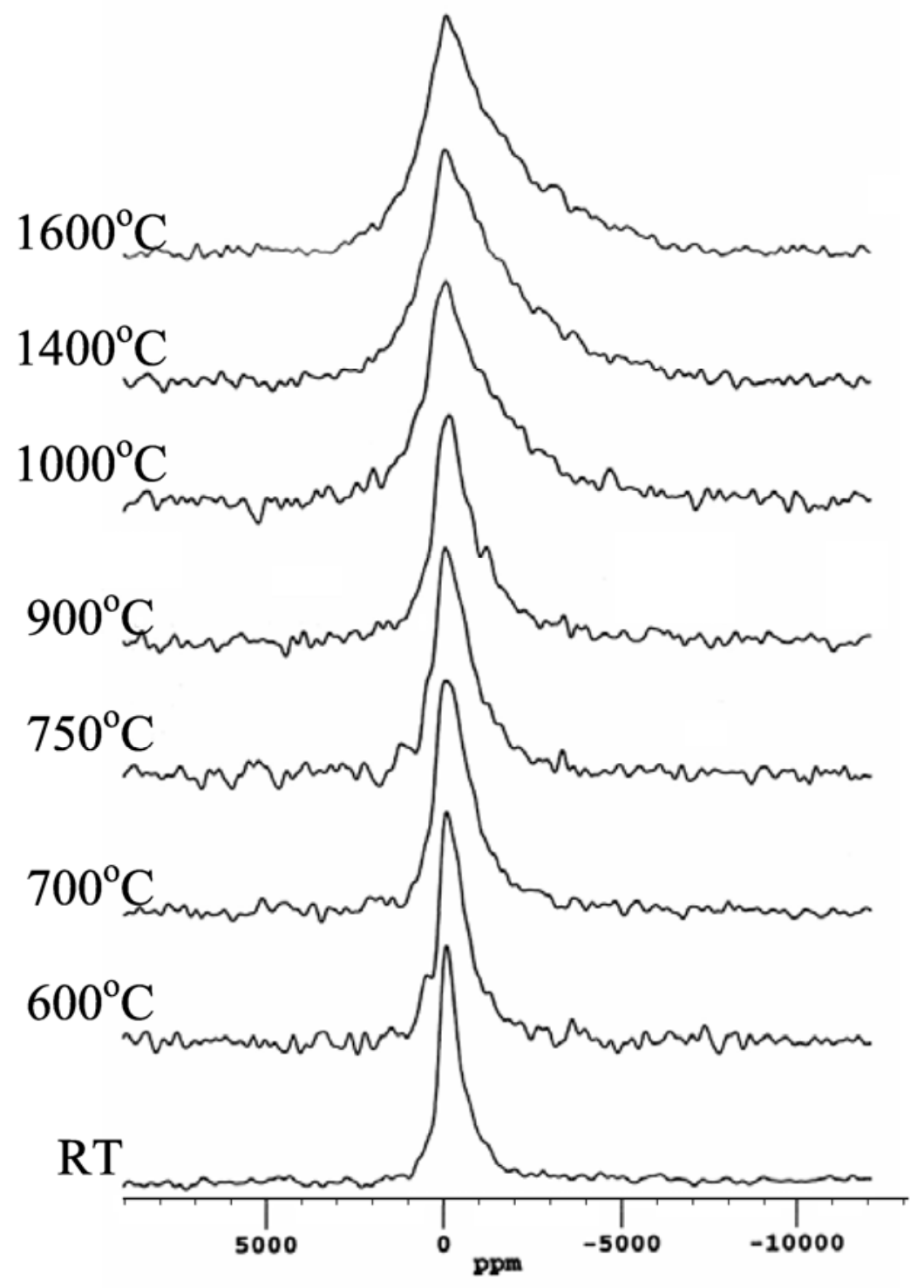

